\title{
Diversity, function, and transcriptional regulation of gut innate lymphocytes
}

\author{
Lucille Rankin $^{1,2 \dagger}$, Joanna Groom ${ }^{1,2 \dagger}$, Lisa A. Mielke ${ }^{1,2}$, Cyril Seillet $^{1,2}$ and Gabrielle T. Belz ${ }^{1,2 *}$ \\ ' Division of Molecular Immunology, The Walter and Eliza Hall Institute of Medical Research, Melbourne, VIC, Australia \\ ${ }^{2}$ Department of Medical Biology, University of Melbourne, Melbourne, VIC, Australia
}

\section{Edited by:}

Eric Vivier, Centre d'Immunologie de Marseille-Luminy, France

\section{Reviewed by:}

Stephen K. Anderson, National Cancer Institute-Frederick, USA Jacques Zimmer, Centre de Recherche Public de la Santé, Luxembourg

\section{*Correspondence:}

Gabrielle T. Belz, Division of Molecular Immunology, The Walter and Eliza Hall Institute of Medical Research, $1 G$ Royal Parade, Parkville, Melbourne VIC 3052, Australia.

e-mail: belz@wehi.edu.au

${ }^{+}$Lucille Rankin and Joanna Groom are equal first authors.
The innate immune system plays a critical early role in host defense against viruses, bacteria, and tumor cells. Until recently, natural killer (NK) cells and lymphoid tissue inducer (LTi) cells were the primary members of the innate lymphocyte family: NK cells form the front-line interface between the external environment and the adaptive immune system, while LTi cells are essential for secondary lymphoid tissue formation. More recently, it has become apparent that the composition of this family is much more diverse than previously appreciated and newly recognized populations play distinct and essential functions in tissue protection. Despite the importance of these cells, the developmental relationships between different innate lymphocyte populations remain unclear. Here we review recent advances in our understanding of the development of different innate immune cell subsets, the transcriptional programs that might be involved in driving fate decisions during development, and their relationship to NK cells.

Keywords: innate lymphocytes, lymphoid tissue inducer cells, progenitor cells, transcription factors, differentiation, lymphoid tissue, immune protection

\section{INTRODUCTION}

Mucosal surfaces of the body are constantly bombarded with a variety of both innocuous and pathogenic organisms. Lymphocytes of the gut-, bronchus-, and nasal-associated lymphoid tissues (GALT, BALT, and NALT, respectively) play a critical role in protecting the body from harmful pathogens that enter through the mucosal tissues and lung.

Innate lymphoid cells (ILCs) are an expanding family of lymphocytes with innate cell characteristics. They co-ordinate the organization of lymphoid tissues, maintain epithelial tissue integrity, are responsible for the anatomical containment of commensal bacteria and play important roles in the protection against pathogens early during infection. Individual populations of ILCs display distinct cytokine signatures in a manner analogous to the specialization of cytokine secretion found in $\mathrm{T}$ helper $(\mathrm{Th})$ cell subsets (Figure 1) which has come to define ILC subsets as innate versions, or perhaps as ancestors, of adaptive Th cells. Importantly, innate lymphocytes produce their effector cytokines in response to non-specific danger signals much more rapidly than their adaptive $\mathrm{T}$ cell counterparts allowing them to act immediately, before antigen specificity is acquired. This rapid induction of effector function allows ILCs to provide front-line protection at the onset of an immune response thereby limiting pathogen spread and regulating homeostatic tissue integrity.

The heterogeneity of ILCs has become increasingly complex. Initially, these cells were categorized based on their dominant expression of a single cytokine and confusingly, many different

Abbreviations: CP, cryptopatch; IL, interleukin; ILC, innate lymphoid cell; ILF, isolated lymphoid follicle; LN, lymph node; NCR, natural cytotoxicity receptor; NK cell, natural killer cell; Ror, retinoic-related orphan. names have been applied to similar populations by the various research groups. As the diversity within the subsets has emerged, the need for consistent nomenclature has become apparent (Spits et al., 2013). It is now suggested that ILCs be grouped into three broad populations based on their phenotype, function, and transcriptional regulation (Tait Wojno and Artis, 2012; Spits et al., 2013; Figure 2). Group 1 ILCs (ILC1) are composed of the prototypical ILC, natural killer (NK) cells. This classification, however, might also include other ILCs that express the transcription factor T-bet and produce interferon- $\gamma$ (IFN- $\gamma$; Spits and Di Santo, 2011; Spits and Cupedo, 2012). Group 2 ILCs (ILC2) produce the Th2 type cytokines interleukin (IL)-5 and IL-13 and are important for helminth expulsion. The group 3 ILCs (ILC3) produce Th17 type cytokines IL-17 and IL-22. They comprise the classical lymphoid tissue inducer (LTi) cells that are responsible for the generation of lymphoid tissue during embryogenesis, LTi-like cells that are phenotypically similar to LTi cells but are enriched in the intestine of the adult, together with the natural cytotoxicity receptor (NCR)-expressing NKp46 ${ }^{+}$ILC that produces IL-22 and not IL-17.

Within these groupings, ILC subsets share some overlapping features in their surface receptor phenotype and cytokine production but are distinct in their requirements for specific different transcription factors. Specification of immune cell fate is a stepwise process encoded by transcription factors that act on committed multi-potent progenitors and sequentially restrict their developmental fate to a particular lineage allowing them to develop into the mature cell type. Much has now been done in defining the regulatory circuits of B cells (Nutt et al., 2011), T cells (Kaech and Cui, 2012), NK cells (Sun and Lanier, 2011; Bezman et al., 2012), and dendritic cells (DCs; Belz and Nutt, 2012), but the lineage 


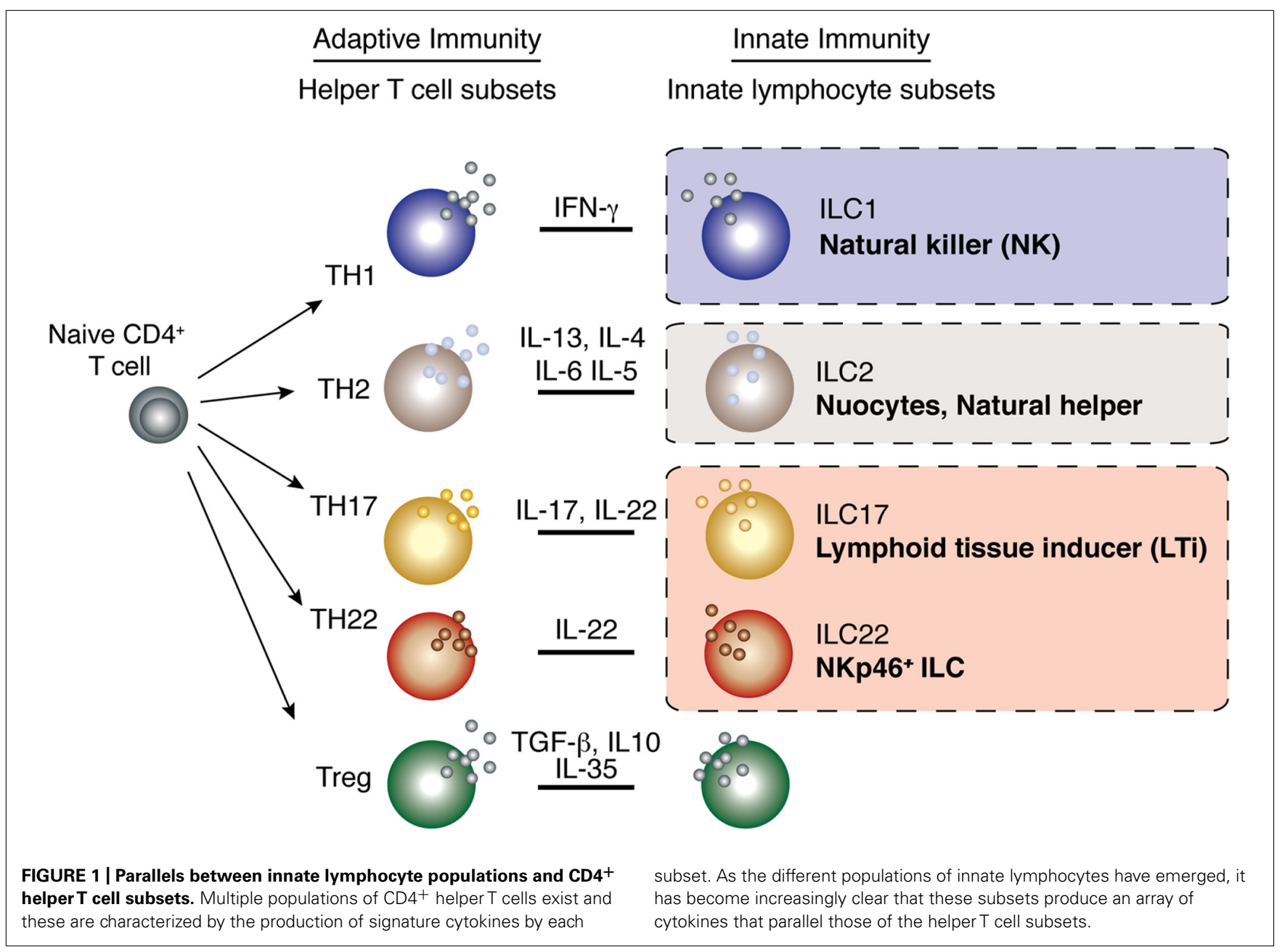

defining transcription factors required for the differentiation of innate lymphocyte subsets is less well understood. Understanding the transcription factors and transcriptional networks that control the differentiation of innate immune cell populations is a rapidly developing area of research.

All ILC subsets are dependent on the transcriptional regulator inhibitor of DNA binding 2 (Id2) while ILC3 cells or Ror $\gamma \mathrm{t}^{+}$ ILCs rely on retinoic acid-related orphan receptor (Ror) $\gamma t$ downstream of Id2. A number of other transcription factors such as Rord, nuclear factor IL-3 [Nfil3, also known as E4-binding protein 4 (E4BP4)], thymocyte selection-associated high-mobility group box protein (Tox), aryl hydrocarbon receptor (Ahr), Runt-related transcription factor (Runx)/CCAAT-binding factor (Cbf $\beta$ ), Gata-binding protein 3 (Gata3), and Notch have also been implicated in the development, survival, and function of these populations.

As yet, the relationships between highly similar ILC populations such as the different subsets of Ror $\gamma \mathrm{t}^{+}$ILCs and whether developmental plasticity enables dynamic inter-conversion between ILC subsets in response to environmental stimuli is unclear. Nevertheless, the recent rapid progress of this research area promises a rich understanding of the complexity of the innate defense system protecting the body's surfaces. Here we review the current knowledge of the transcription factors that regulate the features of ILCs (Figure 2; Table 1).

\section{EARLY DEVELOPMENT OF INNATE LYMPHOCYTES}

The progenitors of innate lymphocytes develop first from common lymphoid progenitors (CLPs) in the fetal liver (Sawa et al., 2010; Vonarbourg et al., 2010) which give rise to multiple lymphoid lineages including B cells, T cells, and ILCs. In the fetal liver $\alpha 4 \beta 7^{+}$CLPs are able to differentiate into NK cells and all subsets of Ror $\gamma \mathrm{t}^{+}$ILCs. The development of ILCs from these precursors is dependent on the expression of Notch, which is regulated differently in fetal and adult precursors (Possot et al., 2011). $\alpha 4 \beta 7^{+}$CLPs are severely reduced in Id2-deficient mice indicating that Id 2 lies upstream of Ror $\gamma t$ in the developmental pathway (Cherrier et al., 2012). These cells also express the chemokine receptor CXCR6 but this marker is not exclusive to LTi cells (Possot et al., 2011). It is proposed that both $\mathrm{CD} 4^{+}$and $\mathrm{CD} 4^{-}$LTi cells arise from a Ror $\gamma \mathrm{t}^{+} \alpha 4^{+} \beta 7^{+}$progenitor while $\mathrm{NKp} 46^{+}$ILCs emerge predominantly from a Ror $\gamma \mathrm{t}^{+} \alpha 4^{+} \beta 7^{-}$cell fraction $\left(\sim 50 \% \mathrm{NKp} 46^{+}\right.$ ILCs) suggesting they are distinct lineages (Narni-Mancinelli et al., 2011). Challenging this concept, it has also been reported that Ror $\gamma \mathrm{t}^{+} \mathrm{NKp} 46^{+}$ILCs can arise from LTi cells following adoptive transfer (Vonarbourg et al., 2010). Recently, our group has 


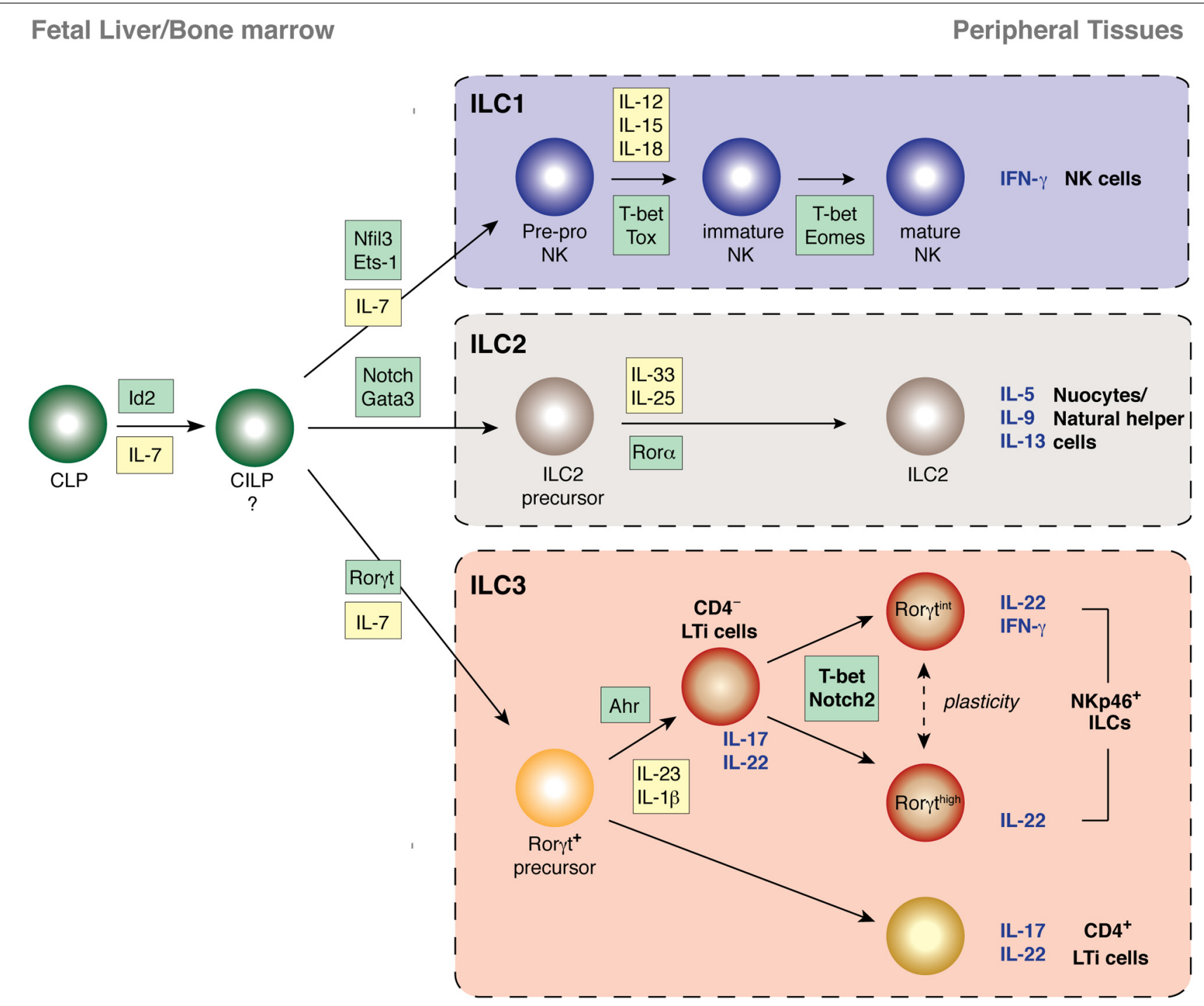

FIGURE 2 | Transcriptional programs controlling the development of innate lymphocyte populations from their progenitor cells in the fetus and adult. The transcription factor Id2 is critical for the development of all NK cells and other ILC populations and is likely to direct the emergence of the common innate lymphoid progenitor (CILP) downstream of the common lymphoid progenitor (CLP) that does not express Id2. The first expression of Id2 from cells derived from the CLP marks the emergence of the pre-pro NK cells, the earliest progenitor of the NK cell lineage. LTi cells and NKp46 ${ }^{+}$ILCs all express and are dependent on Roryt while ILC2 and NK cells develop without passing through a Roryt-dependent stage. ILC2, however, rely on Ror $\alpha$ and Gata3 for their development, expansion, and survival following stimulation. $\mathrm{CD}^{+}$and $\mathrm{CD} 4^{-}{ }^{-} \mathrm{d} 2^{+}{ }^{+} \mathrm{Ror} \gamma \mathrm{t}^{+} \mathrm{LTi}$ cells undergo diversification to generate terminally differentiated NKp46+ ILCs. CD4+ LTi cells appear to have already established a stable phenotype. In contrast, CD4- LTi cells expand in response to various cues such as stimulation through AhR. Further environmental cues induce expression of T-bet and Notch ligands induce Notch signaling which results in the development of NKp46 ${ }^{+}$ILCs that produce abundant IL-22 and protect against bacterial infection. discovered that $\mathrm{NKp} 46^{+}$ILCs arise solely from the $\mathrm{CD} 4^{-}$Ror $\gamma \mathrm{t}^{+}$ ILCs and not the $\mathrm{CD} 4^{+}$LTi subset (discussed in more detail below; Rankin et al., 2013). Thus, we provide evidence that CD4- LTi cells and $\mathrm{NKp} 46^{+}$ILCs are of the same lineage distinct from CD4 ${ }^{+}$LTi (Rankin et al., 2013). This Ror $\gamma \mathrm{t}^{+} \alpha 4 \beta 7^{-}$subset which gave rise to $\sim 50 \% \mathrm{NKp} 6^{+}$cells was unable to generate $\mathrm{CD} 4^{+}$LTi cells but could make CD4- Ror $\gamma \mathrm{t}^{+} \mathrm{NKp} 46^{-}$(Sawa et al., 2010). Therefore, it may be that this progenitor is the true $\mathrm{CD} 4^{-} \mathrm{LTi} / \mathrm{NKp} 46^{+}$ ILC precursor that colonizes that gut while Ror $\gamma \mathrm{t}^{+} \alpha 4 \beta 7^{+}$ cells generate classical LTi cells essential for lymphoid tissue generation.
Natural killer cells, in contrast to LTi cells and NKp46 ${ }^{+}$ILCs do not require Roryt or IL-7 for their development. Until recently, the earliest committed precursor of NK cells, the NKP, was identified through the lack of expression of pan-NK cell markers such as NK1.1 and CD49b and the expression of IL-2R $\beta$ (Rosmaraki et al., 2001). Our recent development of an Id2-GFP (green fluorescent protein) reporter mouse where GFP is expressed under the control of the endogenous Id2 promoter identified that this population was heterogeneous and only a small fraction of cells expressed Id2 (Carotta et al., 2011; Jackson et al., 2011). This population $\left(\operatorname{lin}^{-} \mathrm{CD} 122^{+} \mathrm{NK} 1.1^{-} \mathrm{CD}_{4} 9 \mathrm{~b}^{-} \mathrm{Id} 2-\mathrm{GFP}^{+}\right)$gives rise exclusively to 
Table 1 | Requirement of different transcription factors for lymphoid tissue and ILC development.

\begin{tabular}{|c|c|c|c|c|c|}
\hline $\begin{array}{l}\text { Transcription } \\
\text { factor }\end{array}$ & NK cells (ILC1) & $\begin{array}{l}\text { Nuocytes/natural } \\
\text { helper cells (ILC2) }\end{array}$ & LTi cells (NCR ${ }^{-}$ILC3) & $\begin{array}{l}\text { NKp46+ ILCs } \\
\text { (NCR+ ILC3) }\end{array}$ & Lymphoid tissue organogenesis \\
\hline $\operatorname{ld} 2$ & - & - & - & - & None (Yokota et al., 1999) \\
\hline $\mathrm{ROR} \gamma \mathrm{t}$ & + & + & - & - & Still have NALT (Eberl et al., 2004) \\
\hline $\mathrm{ROR} \alpha$ & + & - & + & + & Normal Mong et al., 2012) \\
\hline Nfil-3 (E4BP4) & - & + & + & + & Normal (Gascoyne etal., 2009) \\
\hline Gata-3 & Lack thymic NK cells & - & + & + & Normal (Hoyler etal., 2012; Mjosberg et al., 2012) \\
\hline AhR & + & $?$ & $\mathrm{CD}^{-}{ }^{-} \mathrm{LTT}$ cells reduced & Reduced & $\begin{array}{l}\text { No ILFs and CP } \\
\text { Normal PP and LN (Lee et al., 2011) }\end{array}$ \\
\hline Tox & Fail to mature & $?$ & Reduced & Reduced & $\begin{array}{l}\text { No LNs; reduced size and number PPs } \\
>90 \% \text { reduced ILCs (Aliahmad et al., 2010) }\end{array}$ \\
\hline Runx/Cbf $\beta 2$ & + & $?$ & Reduced & $?$ & $\begin{array}{l}\text { Impaired organization } \\
\text { Reduced (Tachibana et al., 2011) }\end{array}$ \\
\hline T-bet & Immature & + & + & - & Normal \\
\hline
\end{tabular}

NK cells and has been defined as the pre-pro NK cell. This population has also more recently been identified using the surface marker CD244 and CD27 (Fathman et al., 2011). The induction of Id2-GFP in the pre-pro NK cell identifies the first commitment of progenitors to an NK but not $\mathrm{T}$ or B cell lineage. It will be important to determine the identity of the common innate lymphoid progenitor (CILP) and position it in the developmental tree to gain a greater understanding of the Id2-dependent precursors of ILCs.

\section{INHIBITOR OF DNA BINDING 2}

Inhibitor of DNA binding 2 is a helix-loop-helix (HLH) transcriptional regulator that plays diverse roles in directing lymphocyte development and function. It is part of a group of closely related proteins, Id1-4, that all share the highly conserved HLH motif (Sun et al., 1991; Voronova and Lee, 1994). They regulate transcription by inhibiting the function of E-box proteins. E-box (or E) proteins are another class of transcription factor and include the family members HEB, E2-2, and the E2A gene products E12 and E47 (Murre et al., 1989a,b). E proteins are defined by their two highly conserved domains: (i) a HLH domain which regulates homo- or heterodimerization and (ii) a basic domain is important for binding to E-box sequences on the DNA of target genes (CANNTG; Murre etal., 1989b). Id proteins are able to inhibit E protein function by forming a heterodimer with their complementary E protein via their common HLH domains. As Id proteins lack the basic domain of $\mathrm{E}$ proteins, the Id/E protein heterodimer is unable to bind to DNA and thus transcription is blocked (Sun et al., 1991; Voronova and Lee, 1994). In addition to binding to E proteins, Id proteins have also been shown to interact with other transcription factors including retinoblastoma protein $(\mathrm{Rb})$, the ETS (E-twenty six) and Pax (Paired Box) families (Iavarone et al., 1994; Yates et al., 1999; Roberts et al., 2001).

Inhibitor of DNA binding 2 regulates a diverse number of cell fate decisions during lymphopoiesis. It is involved in the development of effector $\mathrm{CD}^{+}{ }^{+} \mathrm{T}$ cells, DCs, NK cells, and ILCs (Yokota et al., 1999; Hacker et al., 2003; Cannarile et al., 2006; Jackson et al., 2011; Rankin and Belz, 2011). Genetic ablation of Id2 in mice results in the complete failure to develop lymph nodes (LNs), Peyer's patches, and other secondary and tertiary lymphoid tissues including the NALT which is not affected by loss of other transcription factors such as Roryt (Yokota et al., 1999). Loss of the ability to form these lymphoid tissues has been attributed to the lack of LTi cells in these mice although multiple ILC populations are absent and could impact on development (Yokota et al., 1999; Cherrier et al., 2012). Id $2^{-/-}$mice also express a marked reduction in immature NK (iNK) cells in bone marrow and spleen (Boos et al., 2007). In this setting, Id2 acts to inhibit the transcriptional program induced by $\mathrm{E}$ proteins and directs progenitors toward an innate cell lineage as deletion of E2A was able to partially overcome the need for Id2 in LTi cell development and restore the development of lymphoid tissue. In addition, NK cell development in the bone marrow was also restored, however, splenic NK cells were poorly rescued, with only a small number of residual cells which exhibited a thymic rather than splenic NK cell phenotype (Boos et al., 2007). Whether expression of Id2-GFP in an early progenitor also marks the proposed CILP similar to the pre-pro NK cell remains unclear.

\section{Runx/Cbf $\beta$ COMPLEX}

The Runx/Cbf $\beta$ complex has been shown to be involved in the early differentiation pathway of LTi cells (Tachibana et al., 2011). The Runx complex consists of a DNA binding subunit, Runxl, 2 , or 3 and a non-DNA binding partner Cbf $\beta$ that increases the affinity of the Runx subunits for DNA. Runx is essential for the differentiation of several hematopoietic cell lineages including B cells, NK T cells, and CD8 ${ }^{+} \mathrm{T}$ cells (Okuda et al., 1996; Ichikawa et al., 2004; Egawa et al., 2005; Setoguchi et al., 2008). Mice lacking either Runxl or Cbf $\beta$ have defects in lymphoid tissue organogenesis (Tachibana et al., 2011). Runx1/Cbf $\beta$ complexes regulate LTi cell differentiation at distinct stages prior to and following Roryt expression. In both Runx and Cbf-deficient fetuses, there 
was a significant reduction in the frequency of $\operatorname{lin}^{-} \alpha 4 \beta 7^{+} \mathrm{IL}-$ $7 \mathrm{R}^{\text {high }}$ Ror $\gamma \mathrm{t}^{+} \mathrm{LTi}$ precursor cells, a phenotype that parallels that observed in Id2 and Roryt-deficient mice (Tachibana et al., 2011). In contrast to Id 2 and Ror $\gamma \mathrm{t}$ loss, an even earlier, more pluripotent precursor, the $\operatorname{lin}^{-} \alpha 4 \beta 7^{+} \mathrm{IL}_{-} 7 \mathrm{R}^{\text {int }}$ Ror $\gamma \mathrm{t}^{-}$population is reduced in the absence of $C b f \beta$. Thus, Runxl/Cbf $\beta 2$ complexes impair LTi cell development prior to the induction of the Id 2 and Ror $\gamma t$ transcriptional programs. Given this finding, it might be expected that NK cell development would also be significantly affected by loss of Runx1/Cbf $\beta$ complexes. However, NK cells appeared normal in the absence of Runx1/Cbf $\beta$, most likely because NK cells and $\mathrm{CD}^{+} \mathrm{T}$ cells dominantly express Runx3, rather than Runx1 (Ohno et al., 2008). In contrast, Cbf $\beta$ is required for NK cell development (Guo et al., 2008). In the absence of $\operatorname{Cbf} \beta$, lin$^{-}$fetal liver cells produce very few CD122 (IL2R $\beta)^{+}$cells capable of responding to IL-15 which is necessary to generate NK cells. CD122, a subunit of the IL-15R, is directly regulated by $\mathrm{Cbf} \beta$ (Ohno et al., 2008). Nevertheless, transplantation of $C b f \beta$-deficient bone marrow into irradiated recipient adult $\mathrm{C} 57 \mathrm{BL} / 6$ mice revealed that NKP cells could be detected in spleen indicating that NK deficiency occurred at the NKP to iNK cell transition, whereas in fetal liver, NKP could not be detected and thus the block in NK development in the fetus must occur prior to the emergence of NKP.

\section{NATURAL KILLER CELLS (ILC1)}

Natural killer cells form part of the immediate response to pathogens or antigens expressed by transformed (i.e., cancerous or stressed) cells and thus are critical during the innate and adaptive immune responses (Vivier et al., 2011). They are distinct from adaptive cells as they do not express somatically re-arranged antigen-specific surface receptors but instead respond through a repertoire of activating and inhibitory receptors (for example, Ly49 molecules in mice, and killer cell immunoglobulin-like receptors (KIRs) in humans; Raulet et al., 2001; Lanier, 2005). The balance between stress-induced activation of NK cell receptors (such as the natural cytotoxicity triggering receptor 1, NCR-1, encoding NKp46) and major histocompatibility complex class I (MHC class I)-mediated inhibition controls the cytotoxicity of NK cells during pathogen infection and in destruction of tumors.

Natural cytotoxicity receptors are immunoglobulin-like transmembrane glycoproteins which signal through adaptor proteins with intracellular tyrosine-based activation motifs (ITAMs). They are mostly expressed on NK cells. Humans can express NKp30, NKp44, and NKp46 while mice express NKp46 exclusively (Spits and Cupedo, 2012). Gazit etal. (2006) adopted an elegant approach to investigate the role of NKp46 in NK cells by inserting GFP into the Ncrl locus. This enabled direct visualization of NKp46 expression on NK cells during influenza infection where NKp46 recognizes the ligand viral hemagglutinin in a sialic aciddependent manner (Mandelboim et al., 2001). It also showed that NKp $46^{+}$NK cells that accumulated in the lung were critical for the control of lethal influenza. Using this model it has also been demonstrated that NKp46 expression by NK cells is important in controlling tumors (Gazit et al., 2006) and for the development of type-1 diabetes (Gur et al., 2010). Recently, a loss-of-function mutant of NKp46 (Noé mice) has shed light on the mechanism of action of NKp46 (Narni-Mancinelli et al., 2012). Noé mice exhibit a point mutation (W32R) that prevents NKp46 expression on the surface, but did not impair intracellular expression. This phenotype was accompanied by increased responsiveness to stimuli and greater resistance to MCMV and influenza infection. Detailed molecular analyses showed that down-regulation of NK cell activity was associated with silencing of the transcription factor Helios in the NK cells and attenuation of $\mathrm{T}$ cell responses. These studies revealed that NKp46 acts in a dose-specific manner to tune the optimal development of the adaptive immune response.

Murine NK cells require IL-15 signaling through the IL-15R (composed of three subunits, namely IL-15R $\alpha$, CD122, and CD132) for their survival (Mrózek et al., 1996; Kennedy et al., 2000; Cooper et al., 2002; Ranson et al., 2003). Although the majority of NK cells are generated in the bone marrow from CLPs, a developmentally distinct subset of NK cells that arise from bi-potent NK/T cell progenitors in the thymus (Vosshenrich et al., 2006). Bone marrow and thymic-derived NK cells can be clearly differentiated as thymic NK cells require the transcription factor Gata3 for development and are dependent on IL-7, in addition to IL15, for survival (Vosshenrich et al., 2006). They have an immature phenotype with reduced cytotoxic activity and express lower levels of inhibitory receptors including the Ly49 family and CD94 (Vosshenrich et al., 2006). In the bone marrow, multiple stages of NK cell development have been defined on the basis of their phenotype, function, and proliferative capacity (Hayakawa et al., 2006; Huntington et al., 2007). These subsets can be distinguished by the expression of CD27, CD11b (Mac-1), IL-7R, and KLRG-1, which are differentially regulated through maturation (Brady et al., 2004; Hayakawa et al., 2006). iNK cells express low levels of CD11b and the inhibitory receptors CD94 and the Ly49 family, do not express CD49b (DX5) and exhibit low cytotoxicity (Rosmaraki et al., 2001; Kim et al., 2002). During maturation, NK cells up-regulate CD49b, acquire Ly49 and CD94-NKG2 receptor expression then expand to become Mac-1 ${ }^{\text {high }}$ (Kim et al., 2002). Once they mature, NK cells migrate to different tissues including the spleen, LNs, liver, lung, and skin where they develop tissue-specific phenotypes and functions. Furthermore, a unique subset of hepatic NK cells has been described, which constitutively expresses Trail and IL-7R but not Eomesodermin (Eomes) develops independently of the bone marrow (Andrews and Smyth, 2010) and persists as a stable lineage in the liver (Takeda et al., 2005). However, the ontogeny and specific functions of these unconventional NK cells is yet to be fully elucidated.

Natural killer cells found in the intestinal environment are present at low frequencies. Functionally and transcriptionally, they are more similar to other conventional NK (cNK) cells than the intestinal ILCs (Reynders et al., 2011). In the intestinal lamina propria, a large proportion of NK cells express the markers IL-7R and c-Kit and do not express Eomes, a phenotype shared by immature cNK cells, thymic NK cells, and liver-derived NK cells. In addition, an unusually high proportion of these NK cells lack the expression of CD27 and maturation markers such as KLRG-1 and CD11b. Further phenotypic analysis of intestinal NK cells has shown they express only low levels of NKG2D, the Ly49 receptors and exhibit 
low cytotoxic activity, again indicating their immaturity (Sanos et al., 2009). Whether this unique subset of intestinal NK cells are a distinct lineage or alternately are a gut-specific version of thymic or hepatic NK cells has not yet been addressed. Nevertheless, effector molecules such as perforin, granzymes, and IFN- $\gamma$ produced by NK cells following activation play crucial roles in defense against tumors and viral infections. NK cells are therefore thought to represent the innate version of $\mathrm{CD} 4^{+} \mathrm{Th} 1$ cells and cytotoxic $\mathrm{CD} 8^{+}$ T cells (Trinchieri, 1989; Sun and Lanier, 2011).

\section{TRANSCRIPTIONAL REGULATION OF NK CELLS Nuclear factor interleukin-3}

Nuclear factor IL-3 is a critical transcriptional regulator for NK cell development, but does not appear to affect the development of any other ILC subsets (Gascoyne et al., 2009; Kamizono et al., 2009). The blockade in NK development occurs at the NKP to iNK transition. Residual NK cells found in $\mathrm{Nfil}^{-/-}$mice have impaired cytotoxic activity and reduced IFN- $\gamma$ production suggesting that Nfil3 could also be essential for maintaining mature NK cell function (Gascoyne et al., 2009; Kamizono et al., 2009). Nfil3 is induced following IL-15 signaling through the IL-15R and is thought to act prior to the requirement for Id 2 in NK cell development (Gascoyne et al., 2009). Indeed, over-expression of Nfil3 results in an increase in the expression of Id 2 in hematopoietic progenitors and was sufficient to partially rescue NK cell production from progenitors. Thus, Nfil3 was thought to directly induce Id 2 in the NK cells (Gascoyne et al., 2009). This conclusion assumes that Nfil3 and Id 2 lie sequentially in the signaling pathway which may not be the case, as loss of Nfil 3 resulted in only $\sim 30 \%$ reduction in Id 2 expression. An alternate possibility is that Id 2 and Nfil 3 may exert separate critical effects in parallel in these cells.

\section{T-box factors T-bet and Eomes}

T-bet (encoded by Tbx21) and Eomes (encoded by Eomesodermin) are highly homologous T-box transcription factors that play important roles in regulating the function of multiple cell types especially NK cells (Lazarevic and Glimcher, 2011; Gordon et al., 2012). In particular T-bet, like the transcriptional repressor $B$ lymphocyte-induced maturation protein 1 (Blimp1) has been suggested to be involved in maturation and acquisition of effector functions in NK cells (Townsend et al., 2004; Jenne et al., 2009; Kallies et al., 2011). More recently it has been shown that these two transcription factors act in a sequential manner whereby T-bet directs the development of iNK cells and stabilizes the immature phenotype (Gordon et al., 2012). Eomes allows NK expression of a diverse repertoire of Ly 49 receptors and maintenance of a mature phenotype (Gordon et al., 2012). In addition, T-bet and Eomes appear to have distinct roles in the emergence of different NK cell subsets. For example, deficiency of T-bet leads to the loss of hepatic NK cells but not cNK cells (Gordon et al., 2012), suggesting a specific developmental pathway for intrahepatic NK cells (Andrews and Smyth, 2010).

\section{Ets-1}

Ets-1 is a member of the Ets family of winged HLH transcription factors. Ets $-1^{-/-}$mice display significantly reduced splenic NK cells with decreased cytotoxic activity (Barton et al., 1998). The mechanism by which Ets-1 regulates the development and effector function of NK cells has only recently been described. Ets-1 acts at the pre-pro NK stage, directly regulating the expression of Id 2 and T-bet (Ramirez et al., 2012). The residual Ets-1-/- mature NK cells have reduced expression of activating receptors like NKp46, Ly49D, and Ly49H resulting in lower cytotoxic capacity (Barton et al., 1998). Interestingly, Ets-1 $1^{-/}$NK cells also exhibit increased expression of IL-15-regulated genes as well as inhibitory receptors, which is a characteristic of chronically activated NK cells. Thus, Ets- 1 controls a broad range of transcription factors and receptors that drive NK cell development and function (Ramirez et al., 2012).

\section{Tox}

Tox, similar to Id2 and Ikaros, plays a role in the development of both LTi and NK cells. Tox was firstly described as essential for T cell development (Wilkinson et al., 2002; Aliahmad and Kaye, 2008) but subsequent studies have shown Tox ${ }^{-/-}$mice to have severe defects in mature NK cells in the bone marrow and peripheral lymphoid tissues (Aliahmad et al., 2010). Furthermore, knockdown or over-expression studies in human hematopoietic stem cells have also shown Tox to be an important regulator of NK cell development in humans (Yun et al., 2011). In the few remaining Tox ${ }^{-/}$NK cells, Id 2 expression was significantly reduced but unlike in $\mathrm{Nfil}^{-/-}$mice, ectopic expression of Id 2 in Tox ${ }^{-/-}$bone marrow precursors could not rescue NK cell development (Aliahmad et al., 2010). Thus, loss of Id2 expression cannot fully explain the developmental defect observed in Tox ${ }^{-/-}$mice, suggesting that additional regulatory pathways exist for the development of NK cells.

\section{NUOCYTES, NATURAL HELPER CELLS, AND INNATE HELPER CELLS (ILC2)}

Over the last 3 years, a new family of innate lymphocyte has been identified that are able to initiate Th2-like immune responses (Neill and McKenzie, 2011). These have been referred to as natural helper cells (Moro et al., 2010), innate helper cells (Price et al., 2010) and nuocytes (Neill et al., 2010). These populations are Ror $\alpha$-dependent ILCs that express CD278 (ICOS), ST2 (IL33R), and IL-17BR (Scanlon and McKenzie, 2012). Whether these ILCs represent tissue-specific versions of the same cell type is not yet understood, but they can collectively be referred to as ILC2s due to their common production of T helper type 2 cytokines, IL13, IL-5, IL-4, and IL-6 (Moro et al., 2010; Neill et al., 2010; Price et al., 2010; Saenz et al., 2010). These cytokines can activate mast cells, basophils, and eosinophils, which are important for protection against parasitic infections, and have also been implicated in the development of allergic diseases such as asthma (Neill et al., 2010; Neill and McKenzie, 2011). ILC2s expand and secrete these potent Th2 cytokines in response to the IL-17 family member IL25 and the IL-1 family member IL-33 (Moro et al., 2010; Neill et al., 2010). Nuocytes and natural helper cells are $\operatorname{lin}^{-} \mathrm{IL}_{-} 7 \mathrm{R}^{+}$ and express the stem cell markers c-Kit and Sca-1. Natural helper cells were first discovered in clusters of lymphocytes found in adipose tissue termed fat-associated lymphoid tissue (FALT; Moro et al., 2010) while nuocytes have been shown to be essential for the expulsion of helminths during infection (Moro et al., 2010; Neill 
et al., 2010; Price et al., 2010; Saenz et al., 2010). An IL-33 responsive population of ILC2s located in the lung also secrete IL-13 and IL-5. They regulate airway epithelial integrity and promote tissue remodeling following lung disease such as influenza virus infection (Monticelli et al., 2011). During the development of allergic lung disease IL-9 production further promotes secretion of IL-5 and IL-13 in ILCs (Wilhelm et al., 2011). Interestingly, cytokine production in this setting is dependent on collaboration with the adaptive immune response as IL-2 is required for ILC-derived IL-9 production. In turn, these ILC2 cells promote the generation and expansion of IL-13 producing T cells (Neill et al., 2010). Another significant population of IL-33 responsive ILC2s is also present in the intestine of mice and most likely important for helminth expulsion (Hoyler et al., 2012). A human equivalent of the IL-13 ILC has also been identified in nasal polyps of patients with chronic rhino-sinusitis suggesting a role for ILC2s in the pathology of type 2 immunity-associated diseases (Mjosberg et al., 2011).

\section{TRANSCRIPTIONAL REGULATION OF ILC2s Gata-binding protein 3}

Recent evidence suggests that similarities in the transcriptional programs exist between ILC2 and Th2 cells. Gata3 is required for the differentiation and maintenance of ILC2 and is the fate determining transcription factor for differentiation of Th2 cells (Hoyler et al., 2012). Gata3 belongs to the family of transcription factors that bind DNA at the WGATAR motif (Orkin, 1992). It contains two Gata-type zinc fingers and regulates a number of important aspects of $\mathrm{T}$ cell function including the secretion of IL-4, IL-5, and IL-13 (Ho et al., 2009). Mice lacking Gata3 lack IL-13 producing cells, the majority of which are ILC2 cells that express high levels of Gata3 (Moro et al., 2010; Halim et al., 2012; Liang et al., 2012). These mice phenocopy IL-13-deficient mice and display significantly increased susceptibility to Nippostrongylus brasiliensis gut infection. While these observations highlight parallels between Th2 cells and ILC2 cells, NK cells also rely on Gata3 for maturation, expression of homing molecules and production of IFN- $\gamma$ (Samson et al., 2003). Thus, Gata3 plays an important role in terminal differentiation and acquisition of full effector function of multiple innate lymphocyte populations. However, through a cis-acting regulatory element located $280 \mathrm{~kb} \mathrm{3}^{\prime}$ to the Gata3 gene that appears to be both T cell and NK cell-specific (Hosoya-Ohmura et al., 2011), therefore, Gata3 was postulated to play an important role in directing the differentiation of individual innate populations perhaps through the expression of cell-specific enhancers. In parallel with these observations it was discovered that human ILC2s also highly express Gata3 and this expression, together with enhancement of signal transducer and activator of transcription 5 (STAT5) activation, was driven by expression of the cytokine thymic stromal lymphopoietin (TSLP; Mjosberg et al., 2012). These findings emphasize the complexity of the emerging transcriptional network guiding ILC development, and in addition, underline the similarities that exist in the regulation of these innate cell types between mouse and man.

\section{Rord}

Although ILC2s do not require Ror $\gamma$ t for development, it has recently been shown that the highly related transcription factor
Ror $\alpha$ is critical for their terminal differentiation and their capacity to effect immunity against intestinal worms (Wong et al., 2012). This positions Ror $\alpha$ as an essential regulator of the ILC2 lineage downstream from Id2. "Stagger" mice (Ror $\left.\alpha^{\mathrm{sg} / \mathrm{sg}}\right)$ exhibit a spontaneous deletion in Ror $\alpha$ that prevents translation of the ligand-binding homology domain of Ror $\alpha$ and provide a novel tool for investigating the biology of Ror $\alpha$ in the immune system (Hamilton et al., 1996). ILC2s are readily expanded in vivo by the administration of IL-25. In the stagger mice, injection of IL-25 was unable to expand the nuocyte population in contrast to wild-type littermate controls (Wong et al., 2012). Furthermore, loss of the nuocyte population in the lung mucosal tissues resulted in exacerbated responses to asthma, and in the gut, impaired immunity to helminthes infections such as $N$. brasiliensis.

\section{Ror $\gamma$ t-DEPENDENT INNATE LYMPHOID CELLS (ILC3)}

The Ror $\gamma \mathrm{t}$-dependent ILCs are divided into LTi cells, and a heterogeneous population of Ror $\gamma \mathrm{t}^{+}$ILCs found in the intestinal mucosa. These mucosal Ror $\gamma \mathrm{t}^{+}$ILCs include NKp46 ${ }^{+}$ILCs $\left(\mathrm{NCR}^{+}\right.$ILC3) and LTi-like cells $\left(\mathrm{NCR}^{-}\right.$ILC3) populations.

\section{LTi CELLS AND LYMPHOID TISSUE ORGANOGENESIS}

Lymphoid tissue inducer cells were originally reported as an obscure subset of $\mathrm{CD}^{+}{ }^{+} \mathrm{CD} 3^{-}$lymphocytes able to colonize the mesenteric LNs and peripheral LN anlagen in the developing mouse fetus (Kelly and Scollay, 1992; Mebius et al., 1997). It is now known that they are comprised of a heterogeneous population of cells where only a proportion express CD4 and they require signaling through IL-7R for their survival and expansion (Adachi et al., 1998; Yoshida et al., 1999; Finke et al., 2002; Kim et al., 2003, 2008; Lorenz et al., 2003; Mebius, 2003; Eberl et al., 2004; Coles et al., 2006; Satoh-Takayama et al., 2010). They are essential for the formation of lymphoid tissues including LNs and mucosal-associated lymphoid tissues (MALT) which encompasses the NALT, GALT, and BALT.

During fetal development, LTi cells colonize LN and Peyer's patch anlagen where mucosal addressin cell adhesion molecule-1 (MadCam-1), the ligand for $\alpha_{4} \beta_{7}$, is highly expressed (Mebius et al., 1996). They are the first hematopoietic cells recruited to secondary lymphoid tissue where they use $L T \alpha_{1} \beta_{2}$ to interact with the LT $\beta$ R expressed on mesenchymal cells at LN and Peyer's patch anlagen (Yoshida et al., 1999, 2002; Mebius, 2003). Activated mesenchymal cells then express adhesion molecules as well as pro-inflammatory cytokines and chemokines to enable recruitment and organization of lymphocytes in a process similar to inflammation. Tumor necrosis factor activation-induced cytokine (TRANCE) signaling is required for LTi cell accumulation at LN anlagen leading to early embryonic development of peripheral LNs, while the loss of IL-7R leads to an absence in development of both LNs and Peyer's patches (Adachi et al., 1998; Kim et al., 2000).

\section{Ror $\gamma^{+}{ }^{+}$ILCs IN THE INTESTINAL MUCOSA - LTi-LIKE ILCs (NCR- AND $\mathrm{NCR}^{+}$ILC3)}

Subsets of Ror $\gamma \mathrm{t}^{+}$ILCs that are developmentally and functionally similar to LTi cells but show distinct phenotypic differences have been described in the intestinal mucosa. These have 
been termed LTi-like cells. They include $\mathrm{NCR}^{-}$ILC3 which can be further divided into $\mathrm{CD} 4^{-} \mathrm{NKp} 46^{-} \mathrm{CCR} 6^{+/-} \mathrm{Ror} \mathrm{t}^{+}$ and $\mathrm{CD}^{+}{ }^{+} \mathrm{NKp}_{4} 6^{-} \mathrm{CCR}^{+}{ }^{\text {Ror }} \mathrm{t}^{+}$subsets, and $\mathrm{NCR}^{+}$ILC3s $\left(\mathrm{CD} 4^{-} \mathrm{NKp} 46^{+}{\text {Ror } \gamma \mathrm{t}^{+}}^{+}\right.$.

These Ror $\gamma \mathrm{t}^{+}$ILCs are most highly represented in tertiary lymphoid structures of the GALT. CD4 ${ }^{+}$LTi cells are most prominent at birth and appear to be involved in the formation of Peyer's patches. However, after birth, CD4 ${ }^{+}$LTi only make up $15-20 \%$ of the $\mathrm{NCR}^{-} \mathrm{ILC}^{+}$populations when the $\mathrm{CD}^{-}{ }^{-} \mathrm{LTi}$ cells and $\mathrm{NKp} 46^{+}$ILCs rapidly expand at the same time as microbial colonization, indicating an important interplay between their development and environmental signals.

\section{LTi-LIKE ILCS (NCR- ILC3) IN THE GENERATION OF TERTIARY LYMPHOID TISSUE}

Secondary lymphoid tissue of the GALT, namely mesenteric LN and Peyer's patch develop in an organized and programed way involving fetal LTi cells, whereas tertiary lymphoid structures develop in response to the environmental cues from microbiota and surrounding tissue and are thought to involve $\mathrm{NCR}^{-}$ILC3 CD4 ${ }^{-}$or $\mathrm{CD}^{+}{ }^{+}$cells (Lorenz et al., 2003; Eberl et al., 2004; Ota et al., 2011). Here, LTi-like cells are able to induce the development of well-organized lymphoid structures capable of carrying out germinal center reactions and promote immunoglobulin A (IgA) class switching in response to inflammation (Lorenz et al., 2003; Tsuji et al., 2008). They are key effector cells that drive both the size and number of cryptopatches (CPs) and isolated lymphoid follicles (ILFs) in the gut tissues.

\section{NKp46+ ILCs (NCR ${ }^{+}$ILC3)}

A major subset of intestinal Ror $\gamma \mathrm{t}^{+}$ILCs express the surface molecule NKp46 in addition to the transcription factors Ror $\gamma \mathrm{t}$ and Id2. NKp46 ${ }^{+}$ILCs rely on IL-7 signaling for survival and are themselves potent producers of IL-22 but unlike NCR ${ }^{-}$ILC3s do not produce IL-17 (Satoh-Takayama et al., 2008, 2010; Reynders et al., 2011). NKp46 ${ }^{+}$ILCs reside mainly in CPs, but are also found in ILFs, Peyer's patches and at very low frequencies in the mesenteric LNs (Luci et al., 2009). NKp46 ${ }^{+}$ILCs can be further divided according to their expression level of Ror $\gamma \mathrm{t}$ and NK1.1 into Ror $\gamma \mathrm{t}^{\mathrm{hi}} \mathrm{NK} 1.1^{\mathrm{lo} /-}$ and Ror $\gamma \mathrm{t}^{\mathrm{int}} \mathrm{NK} 1.1^{\text {int }}$ populations, however whether these are distinct subsets remains unclear (Luci et al., 2009). The human counterpart for NKp46 ${ }^{+}$ILCs are defined by their expression of NKp44 rather than NKp46 (Crellin et al., 2010). NKp46 was originally presumed to be exclusively expressed by NK cells. It was therefore assumed that NKp $46^{+}$ILCs were most closely related to NK cells, however, $\mathrm{NKp} 46^{+}$ILCs are distinct from NK cells in several fundamental ways. NKp46 is not essential for the development or function of NKp46 ${ }^{+}$ILCs, which contrasts with the important role of NKp46 in NK cells (Satoh-Takayama et al., 2009; Narni-Mancinelli et al., 2011). IL-15 is essential for the differentiation, survival, and activation of NK cells but is not required for the development of NKp46 ${ }^{+}$ILCs, which like LTi cells depend on the cytokine IL-7 (Satoh-Takayama et al., 2009, 2010). Functionally, NKp46 ${ }^{+}$ILCs also differ from NK cells as they produce little IFN- $\gamma$, no perforin and show little cytotoxic potential (SatohTakayama et al., 2008; Reynders et al., 2011). An exception to this is Ror $\gamma \mathrm{t}^{\mathrm{int}} \mathrm{NKp} 46^{+}$ILCs that can be induced to produce IFN- $\gamma$ during intestinal inflammation and are potent inducers of colitis (Vonarbourg et al., 2010).

\section{Roryt ${ }^{+}$ILCs during inflammation}

In addition to the key role Ror $\gamma \mathrm{t}^{+}$ILCs play in the development of lymphoid tissues in the intestinal mucosa, they are crucial for maintaining epithelial integrity through the production of IL-22 and IL-17, signature cytokines secreted by IL-17 producing Th cells (Wolk et al., 2004; Ivanov et al., 2006; Zheng et al., 2007; Pickert et al., 2009; Takatori et al., 2009; Vivier et al., 2009; Ota etal., 2011). ILCs are the main producers of IL22 in the intestine following stimulation by IL-23 produced by activated intestinal DCs (Sawa et al., 2011; Cox et al., 2012). Interestingly, at steady state the adaptive immune system represses IL-22 production by ILCs, however this is de-repressed following epithelial damage (Sawa etal., 2011). IL-22 activates the transcriptional regulator STAT3 and triggers production of antimicrobial molecules such as $\beta$-defensin, lipocalin-c and Reg family proteins from epithelial cells to limit pathogen survival and dissemination (Liang et al., 2006; Sugimoto, 2008; Zheng et al., 2008; Sonnenberg et al., 2011). IL-17 is a pro-inflammatory cytokine that promotes neutrophil recruitment and activation and is also enhanced by IL-23 (Takatori et al., 2009). In contrast to LTi cells, murine NKp46 ${ }^{+}$ILCs are not known to produce IL-17 (Luci et al., 2009; Sawa etal., 2011) although the complete spectrum of cytokines that this population does produce during inflammation has not been fully assessed. Roryt is known to regulate IL-17, so it is intriguing that these Ror $\gamma \mathrm{t}^{+}$ILCs lack production of this cytokine implying different transcriptional regulation of cytokines in NKp46 ${ }^{+}$ILCs compared with LTi cells. The importance of IL-23 induced IL-22 production by Ror $\gamma \mathrm{t}^{+}$ILCs is demonstrated during experimental models of intestinal inflammation such as Citrobacter rodentium, as mice deficient in these cells rapidly succumb to infection (Satoh-Takayama et al., 2008; Zheng et al., 2008). Here, ILC-derived IL-22 can be induced by lymphotoxin- $\beta$ in the presence of IL-23 and reduces the systemic dissemination of bacteria from the colon to the liver and spleen (Ota et al., 2011; Sonnenberg et al., 2011). While IL-17 and IL-22 are important to maintain intestinal homeostasis and protect against intestinal pathogens, aberrant production of these cytokines has been associated with inflammatory bowel disease and colon cancer. IL-17 produced by ILCs is thought to be one of the key cytokines in driving colon inflammation in an innate model of Helicobacter hepaticus driven colitis (Buonocore etal., 2010). Human studies show that IL-17 production and the frequency of ILCs increases in patients with inflammatory bowel disease (Geremia et al., 2011). IL-22 can also promote intestinal disease by enhancing epithelial cell proliferation leading to colon cancer (Huber et al., 2012). Therefore it is important to understand the activating factors and molecular pathways controlling IL-17 and IL-22 production as this will eventually lead to the development of improved treatments for intestinal disease.

NKp $46^{+}$ILCs are a critical source of IL-22 but despite this, the relative contribution of IL-22 secreted from NKp46 ${ }^{+}$ILCs or other LTi-like cell subsets is not clear. Until recently, the extent to which one population might dominate or compensate for the other may 
depend on the type of mucosal activation was unclear, however we have recently shown that other Ror $\gamma \mathrm{t}^{+}$cells cannot compensate for the absence of IL-22 producing NKp46 ${ }^{+}$ILCs during C. rodentium infection (Rankin et al., 2013).

\section{Roryt $^{+}$ILCs and commensal microflora}

During steady state, Ror $\gamma \mathrm{t}^{+}$ILCs play critical roles in maintaining mucosal homeostasis through responding to carefully regulated signals from the epithelial layer and commensal bacteria in the intestine. Firstly, the induction of ILFs from CPs occurs in response to external stimuli such as peptidoglycan from gram-negative bacteria in the gut lumen (Bouskra et al., 2008). In this situation, B cells and other lymphocytes are recruited to CPs in a lymphotoxin receptor-dependent manner (Lorenz et al., 2003; Bouskra et al., 2008). Interestingly, ILFs do not develop in germ-free mice, but instead remain as CPs (Hamada et al., 2002; Pabst et al., 2006; Bouskra etal., 2008). Therefore, the number of CPs, ILFs and commensal microflora are tightly controlled by a dynamic activatory/inhibitory negative feedback loop (Bouskra et al., 2008). Increased formation of ILFs enhances the capacity of the immune system to target responses toward the luminal bacteria. In turn, this restricts bacterial proliferation and invasion and serves to shut down the signals that induce ILFs (Sawa et al., 2010; Ota et al., 2011; Sonnenberg et al., 2011). Adult LTi cells become activated and induce recruitment of other lymphocytes through a chemokinemediated network. CCR6 responds to signaling from CCL20 (also known as MIP-3 $\alpha$ ), a molecule highly expressed by the epithelium overlying Peyer's patches and ILFs. $\beta$-defensin 3 also binds CCR6 and is expressed by inflamed epithelia and intestinal CPs. Thus, it is suggested that Ror $\gamma \mathrm{t}^{+}$ILCs depend on CCR6 responses to CCL20 and $\beta$-defensin signaling (Sawa et al., 2010).

Secondly, Ror $\gamma \mathrm{t}^{+}$ILCs constitutively produce IL-22 where the levels are controlled by careful integration of signals from commensal bacteria and the epithelial layer. Vonarbourg et al. (2010) also showed that commensal microflora and IL-7 can act to stabilize Roryt expression within the NKp46 ${ }^{+}$ILC population, but they apparently do not induce their differentiation. Other reports have shown that intestinal microbiota have no effect on relative or absolute numbers of ILCs in the gut (Reynders et al., 2011; Sawa et al., 2011) while earlier reports showed a reduction in $\mathrm{NKp} 46^{+}$ ILCs, but not LTi cells in germ-free mice suggesting a role for commensal microflora in directing their development and function (Satoh-Takayama et al., 2008; Sanos et al., 2009; Vonarbourg et al., 2010). It has now been reported that the absence of microflora enhanced the ability of NKp46 ${ }^{+}$ILCs to produce IL-22 (Reynders et al., 2011; Sawa et al., 2011). The microbiota were shown to induce IL-25 expression on epithelial cells which in turn inhibited NKp46 ${ }^{+}$ILC IL-22 secretion (Sawa et al., 2011). As IL-25R is not expressed on Ror $\gamma \mathrm{t}^{+}$ILCs, this must be occurring via an intermediate cell type such as intestinal DCs. While analyses of the contribution of microbiota to the development, function, and proliferation of ILCs has been investigated, virtually nothing is known about how the individual ILC populations might modify the microbiome.

Thirdly, in a recent elegant study, intestinal ILCs were shown to be crucial for the anatomical containment of commensal bacteria during steady state (Sonnenberg et al., 2012). Here ILCs were depleted in $\mathrm{Rag}^{-/-}$mice and a specific species of commensals that reside in Peyer's patches and mesenteric LNs named Alcaligenes disseminated to the liver and spleen. This resulted in systemic inflammation and increased levels of lipopolysaccharide (LPS). As such, ILCs were crucial for the specific anatomic containment of Alcaligenes through the production of IL-22.

\section{TRANSCRIPTIONAL REGULATION OF ILC3 Roryt}

The orphan nuclear receptor Ror $\gamma t$ is an important transcription factor involved in lymphocyte development. It belongs to a large family of steroid hormone receptors that include receptors for steroids, retinoids, thyroid hormones, and vitamin $\mathrm{D}_{3}$ and are important regulators of development, cell differentiation, and organ physiology (Mangelsdorf et al., 1995). Ror $\gamma \mathrm{t}$ is encoded by the Rorc gene and encodes two isoforms, Ror $\gamma$ and Ror $\gamma$ t from distinct promoters (He et al., 1998; Villey et al., 1999). While the mRNA of the first isoform, Ror $\gamma$, is detectable in many tissues, the expression of Ror $\gamma \mathrm{t}$ is limited to a small number of lymphocyte populations. Ror $\gamma t$ is highly expressed in double positive (DP) thymocytes (Villey et al., 1999; Sun et al., 2000). The thymus of mice deficient in Ror $\gamma t$ is dramatically decreased in size and cellularity (Kurebayashi et al., 2000; Sun et al., 2000). This is mainly due to the reduced number of $\mathrm{CD} 4{ }^{+} \mathrm{CD} 8^{+} \mathrm{DP}$ thymocytes that results in the reduction of mature single positive $\left(\mathrm{CD} 4^{+} \mathrm{CD} 8^{-}\right.$or $\left.\mathrm{CD} 4^{-} \mathrm{CD} 8^{+}\right)$ thymocytes. Ror $\mathrm{t}^{-/}$thymocytes also show increased levels of apoptosis due to the failure of induction of the pro-survival protein Bcl-xL in the absence of Roryt (Eberl and Littman, 2004). It was therefore proposed that Roryt prolongs the lifespan for DP thymocytes allowing them a greater chance to undergo positive selection (Kurebayashi et al., 2000). Beyond its role in thymocyte development, Roryt expression does not appear again in the $\mathrm{T}$ cell development program until peripheral $\mathrm{CD}^{+}{ }^{+} \mathrm{Th}$ cell subsets undergo differentiation. In this population, Ror $\gamma \mathrm{t}$ is induced in response to IL- 6 and transforming growth factor beta (TGF- $\beta$ ) signaling to drive naïve $\mathrm{CD} 4{ }^{+} \mathrm{T}$ cells toward a Th17 fate characterized by the production of IL-22 and IL-17 (Ivanov et al., 2006). In the absence of Ror $\gamma \mathrm{t}$, naïve $\mathrm{CD} 4^{+} \mathrm{T}$ cells are unable to differentiate into Th17 cells.

Similar to Id2-deficient mice, Roryt null mice lack secondary lymphoid tissues due to the absence of LTi cells (Sun et al., 2000; Eberl and Littman, 2003). This includes LNs, Peyer's patches, ILFs, and CPs. However, in contrast to Id2-deficient mice, NALT development remains unperturbed in the absence of Ror $\gamma$ t (Eberl and Littman, 2003). Using the elegant Ror $\gamma t^{\mathrm{GFP} / \mathrm{GFP}}$ mouse strain (which are deficient in Roryt) it has demonstrated that both LTi cells and all subsets of Ror $\gamma \mathrm{t}^{+}$ILCs in the intestine are dependent on Ror $\gamma t$ for their development while NK cells and nuocytes are unaffected (Eberl et al., 2004; Satoh-Takayama et al., 2008; Luci et al., 2009; Sanos et al., 2009; Moro et al., 2010; Neill et al., 2010; Vonarbourg et al., 2010). Recent microarray and fate mapping experiments on cells expressing the cell surface receptor NKp46 further support the notion that Ror $\gamma t$ is a lineage defining transcription factor for the all ILC3 cells as intestinal NK cells and $\mathrm{NCR}^{+}$ILC3s were shown to represent two distinct lineages both genetically and developmentally (Narni-Mancinelli et al., 2011; Reynders et al., 2011). 


\section{Tox}

In addition to it's essential role during NK development (above), Tox is also required for the development and maturation of innate lymphocytes (Neill and McKenzie, 2011). Tox $x^{-/-}$mice have 90\% reduction in LTi cells in the spleen of neonates and NKp46 $6^{+}$ ILCs are also diminished (Aliahmad et al., 2010). In contrast to mice that lack $I d 2$, in the absence of Tox, Peyer's patches still develop but their size and number are severely reduced. Overexpression of Id 2 was unable to recover a normal phenotype in the Tox $x^{-/}$LTi cells suggesting that Tox is downstream of Id2. However, such experimental approaches do not excluded that Id2 and Tox may not lie in the same linear pathway, or that Tox may regulate other critical Id2-independent steps in ILC development. In addition, the role of Tox in specific subsets of intestinal ILCs, including NKp46 ${ }^{+}$ILCs, were not investigated in detail in this study. Nevertheless, although Tox and Id 2 are both highly influential in regulating the development of NK and LTi cells, Tox appears to act later and differentially affects Peyer's patches and LN formation (Aliahmad et al., 2010).

\section{Aryl hydrocarbon receptor}

Aryl hydrocarbon receptor is a ligand-dependent transcription factor that is a member of the basic HLH/Per-Arnt-Sim (bHLH/PAS) family. AhR is a cytosolic transcription factor bound to co-chaperones such as hsp90 and is normally inactive. On ligand binding, it dissociates from its chaperones and translocates to the nucleus dimerizing with the AhR nuclear translocator (ARNT) that results in changes to gene transcription (Burbach etal., 1992). AhR is a sensor of a number of chemicals and environmental toxins including as 2,3,7,8-tetrachlorodibenzo- $p$ dioxin (TCDD) and phytochemicals such as indole-3-carbinol found in cruciferous vegetables such as cauliflower and cabbage. Endogenous ligands such as the tryptophan photoproduct 6-formylindolo-3,2-b-carbazole (FICZ) have also been identified.

Aryl hydrocarbon receptor has been shown to affect the differentiation of regulatory T cells (Tregs) and enhance the production of IL-17 from Th17 cells. Furthermore, AhR is necessary to allow Th17 cells to produce IL-22 (Kimura et al., 2008; Quintana et al., 2008; Veldhoen et al., 2009; Mezrich et al., 2010). Recently mice lacking AhR have been shown to exhibit a significant deficit in CD4 ${ }^{-}$LTi cells and NKp46 ${ }^{+}$ILCs in the intestinal mucosa (Kiss et al., 2011; Qiu etal., 2012). As the Roryt ILCs were not completely ablated, it appears that $\mathrm{AhR}$ is required for the expansion and survival of CD4 ${ }^{-}$LTi cells and NKp46 ${ }^{+}$ILCs following microbial colonization of the intestine after birth rather than their development. CD4 ${ }^{+}$LTi cells were also affected albeit mildly (Kiss et al., 2011). Extending these studies in an elegant set of experiments it was shown that although $A h R$-deficient mice lack ILFs and CPs, they have normal Peyer's patch development (Lee et al., 2011). Thus, AhR is specifically required in the formation of postnatal lymphoid tissues highlighting the differential requirements of Ror $\gamma \mathrm{t}^{+}$ILC subsets for ILF and Peyer's patch development. Investigation into AhR target genes required for ILC development showed that inhibition of the Notch signaling pathway, which is regulated by AhR, critically affected ILC populations.

\section{Notch}

Notch proteins (Notch1-4) are transmembrane receptors that bind to the surface ligands Delta-like or Jagged before induction of proteolytic cleavage to release the Notch intracellular domain (ICN). On release, ICN translocates to the nucleus where it binds to the CSL/RBP-J (CBF-1/RBP-J, Suppressor of Hairless, Lag-1) transcription factor displacing co-repressors and recruiting co-activators of the Mastermind-like family (MAML). Notch signaling in developing lymphocytes is complex (Bray, 2006). In peripheral $\mathrm{CD}^{+} \mathrm{T}$ cells, Notch-1 plays an important role in Th1 polarization (Minter et al., 2005). Both Notch-1 and Notch-2 together with the canonical effector RBPJ (recombination signal binding protein for the immunoglobulin kappa J region) act to protect activated cells against apoptosis (Helbig et al., 2012). In innate lymphocytes, Notch-2 was strongly implicated in the development of adult, but not fetal, Ror $\gamma \mathrm{t}^{+}$cells due to the differentiation of progenitors in response to the stromal cell OP9 expressing the Notch ligand DL-4 (Possot et al., 2011). Disruption of Notch signaling, by the deletion of RBPJ, reduced the number of $\mathrm{NK}_{4} 6^{+}$ILCs in the small intestine though it had only a marginal effect on other Ror $\gamma \mathrm{t}^{+}$ILC subsets and thus ILF and CP development and this was thought to be downstream of Ahr (Lee et al., 2011). The circuitry regulating the differential dependence of Notch in different ILC subsets appears to depend largely on the induction of T-bet (Rankin et al., 2013).

\section{T-bet}

The role of T-bet in the development of innate lymphocytes has not previously been investigated except in NK cells. Our recent data showed that T-bet was highly expressed by both the Roryt intermediate and high populations of NKp46 ${ }^{+}$ILCs but not the NKp $46^{-}$Ror $\gamma t^{+}$ILCs. Indeed, T-bet was found to be essential for the differentiation of NKp46 ${ }^{+}$ILCs (Rankin et al., 2013). Furthermore, T-bet was crucial for the transition from CD4 ${ }^{-}$Ror $\mathrm{t}^{+}$ LTi cells into Ror $\gamma \mathrm{t}^{+} \mathrm{NKp} 46^{+}$ILCs and this transition depended on Notch signaling. Interestingly, both ILC subsets were strongly affected by the absence of Ahr, indicating that CD4 ${ }^{-}$LTi cells are a lineage distinct from CD4 ${ }^{+}$LTi cells (Kiss et al., 2011). Similar to NK cells, Blimp1 was also exclusively expressed by $\mathrm{NKp} 46^{+}$ ILCs but was not required for their development (Rankin et al., 2013). In contrast to NK cells, we did not observe any expression of Eomes in NKp46 ${ }^{+}$ILCs or LTi cells indicating that Eomes and T-bet operate in a non-redundant manner in this lineage. This identifies T-bet as a master regulator of NKp46 ${ }^{+}$ILC differentiation and the $\mathrm{CD}^{-}{ }^{-}$LTi subset as their direct precursor through the T-bet-Notch signaling pathway (Rankin et al., 2013).

\section{CONCLUSION}

In the past 3 years, it has been clear that innate lymphocytes comprise a heterogeneous group of cells composed of individual populations with discrete, yet complementary functions in maintaining tissue homeostasis and providing protection during an immune responses.

Teasing apart the intrinsic and extrinsic regulatory circuits that result in the development and functional contributions of the various innate lymphocyte populations during inflammation or infection is both an exciting and evolving story. Significant 
progress has been made in identifying some of the key transcriptional regulators required for the differentiation of ILC subsets, but how they are regulated remains unclear. For example, whether Id 2 lies up- or downstream of Nfil3 will require re-examination; or where the terminal differentiation of Ror $\gamma \mathrm{t}$-dependent lineages lies, especially where LTi cells branch off from $\mathrm{NCR}^{+}$and $\mathrm{NCR}^{-}$ ILC3s. This may also facilitate further understanding of whether different phenotypes of cells within an ILC population represents a unified lineage that differs because of localization in the body, or they are related but distinct populations within a lineage (e.g., understanding the relationship between the highly similar nuocytes and natural helper cells). Future studies will be important in dissecting these pathways and in understanding the specific contributions ILC subsets make to immunity and pathology in different inflammatory settings.

In the adult tissues, particularly the gut, how the different subsets of Ror $\mathrm{t}^{+}$ILCs are developmentally related has remained contentious. It is possible that $\mathrm{NKp} 46^{+}$ILCs develop as direct progeny of LTi cells or alternately they may arise from a closely related but distinct cell type. Our recent data show that $\mathrm{NKp} 46^{+}$ ILCs are in fact the direct progeny of $\mathrm{CD}^{-}$LTi cells isolated from the small intestinal lamina propria. However, in a separate study, LTi cells cultured in vitro under various conditions were unable to be induced to express NKp46 supporting that the adult phenotypes of gut ILCs remain stable (Sawa et al., 2011). This may be because the conditions used in these experiments were not optimal to induce differentiation. Nevertheless, a highly specific set of signals from the environment and neighboring cells that induce transcription factors such as T-bet, Notch, Ahr, and other signaling molecules drive the differentiation of $\mathrm{NKp} 46^{+}$ ILCs. However, in order to understand how innate lymphocytes are regulated in the gut during steady state and disease to effect protective immunity, it will be essential to elucidate further the developmental and micro-environmental requirements of the ILC

\section{REFERENCES}

Adachi, S., Yoshida, H., Honda, K., Maki, K., Saijo, K., Ikuta, K., et al. (1998). Essential role of IL-7 receptor alpha in the formation of Peyer's patch anlage. Int. Immunol. 10, $1-6$.

Aliahmad, P., de la Torre, B., and Kaye, J. (2010). Shared dependence on the DNA-binding factor TOX for the development of lymphoid tissueinducer cell and NK cell lineages. Nat. Immunol. 11, 945-952.

Aliahmad, P., and Kaye, J. (2008). Development of all CD4 $\mathrm{T}$ lineages requires nuclear factor TOX. J. Exp. Med. 205, 245-256.

Andrews, D. M., and Smyth, M. J. (2010). A potential role for RAG1 in NK cell development revealed by analysis of $\mathrm{NK}$ cells during ontogeny. Immunol. Cell Biol. 88, 107-116.

Barton, K., Muthusamy, N., Fischer, C., Ting, C. N., Walunas, T. L., Lanier, L. L., et al. (1998). The Ets-1

family. In addition, the degree of plasticity between the various Ror $\gamma \mathrm{t}^{+}$populations is not yet clear. It will be important to uncover whether NKp46 ${ }^{+}$ILCs are a terminally differentiated cell type or, as shown for Th cell subsets, they are in dynamic equilibrium with CD4 ${ }^{-}$LTi cells responding to environmental cues.

A third key question for the field revolves around determining the identity of the CILP as well as the molecules and steps involved in lineage branching to form the different ILC subsets. Id2 is an essential core regulator of the development of the innate lymphocyte family and although the exact identity of the CILP remains to be elucidated it will most likely be an Id2 expressing cell.

Finally, although it is widely recognized that Id2 and Roryt are essential regulators of a number of ILC populations, the downstream molecular targets of these transcription factors in the LNs and Peyer's patch have not yet been identified. At a cellular level, elucidating whether the attributes of different ILC populations are shared or distinct, whether there exists plasticity between the populations and whether they develop locally from precursors, or alternately are recruited through the blood will be important in understanding how ILCs orchestrate robust mucosal protection and provide insight into potential avenues to harness and manipulate these cells to promote or ameliorate immune responses.

\section{ACKNOWLEDGMENTS}

This work is supported by the National Health and Medical Research Council (NHMRC) of Australia. Gabrielle T. Belz is supported by an Australian Research Council Future Fellowship, Lucille Rankin is supported by an NHMRC Dora Lush Fellowship and Joanna Groom is supported by an NHMRC International Postdoctoral Fellowship. This work was made possible through Victorian State Government Operational Infrastructure Support and Australian Government NHMRC IRIIS.

Brady, J., Hayakawa, Y., Smyth, M. J., and Nutt, S. L. (2004). IL-21 induces the functional maturation of murine NK cells. J. Immunol. 172, 2048-2058.

Bray, S. J. (2006). Notch signalling: a simple pathway becomes complex. Nat. Rev. Mol. Cell Biol. 7, 678-689.

Buonocore, S., Ahern, P. P., Uhlig, H. H. Ivanov, I. I., Littman, D. R., Maloy, K. J., et al. (2010). Innate lymphoid cells drive interleukin-23-dependent innate intestinal pathology. Nature 464, 1371-1375.

Burbach, K. M., Poland, A., and Bradfield, C. A. (1992). Cloning of the Ahreceptor cDNA reveals a distinctive ligand-activated transcription factor. Proc. Natl. Acad. Sci. U.S.A. 89, 8185-8189.

Cannarile, M. A., Lind, N. A., Rivera, R., Sheridan, A. D., Camfield, K. A. Wu, B. B., et al. (2006). Transcriptional regulator Id 2 mediates CD8+ $\mathrm{T}$ cell immunity. Nat. Immunol. 7, 1317-1325.
Carotta, S., Pang, S. H. M., Nutt, S. L., and Belz, G. T. (2011). Identification of the earliest NK-cell precursor in the mouse BM. Blood 117, 5449-5452.

Cherrier, M., Sawa, S., and Eberl, G. (2012). Notch, Id2, and ROR $\gamma \mathrm{t}$ sequentially orchestrate the fetal development of lymphoid tissue inducer cells. J. Exp. Med. 209, 729-740.

Coles, M. C., Veiga-Fernandes, H., Foster, K. E., Norton, T., Pagakis, S. N., Seddon, B., et al. (2006). Role of T and NK cells and IL7/IL7r interactions during neonatal maturation of lymph nodes. Proc. Natl. Acad. Sci. U.S.A. 103, 13457-13462.

Cooper, M. A., Bush, J. E., Fehniger, T. A., VanDeusen, J. B., Waite, R. E., Liu, Y., et al. (2002). In vivo evidence for a dependence on interleukin 15 for survival of natural killer cells. Blood 100 , 3633-3638.

Cox, J. H., Kljavin, N. M., Ota, N., Leonard, J., Roose-Girma, M., Diehl, 
L., et al. (2012). Opposing consequences of IL-23 signaling mediated by innate and adaptive cells in chemically induced colitis in mice. Mucosal Immunol. 5, 99-109.

Crellin, N. K., Trifari, S., Kaplan, C. D., Cupedo, T., and Spits, H. (2010). Human NKp44+IL-22+ cells and LTi-like cells constitute a stable RORC+ lineage distinct from conventional natural killer cells. J. Exp. Med. 207, 281-290.

Eberl, G., and Littman, D. R. (2003). The role of the nuclear hormone receptor RORgammat in the development of lymph nodes and Peyer's patches. Immunol. Rev. 195, 81-90.

Eberl, G., and Littman, D. R. (2004). Thymic origin of intestinal alphabeta $T$ cells revealed by fate mapping of RORgammat+ cells. Science 305 , 248-251.

Eberl, G., Marmon, S., Sunshine, M.-J., Rennert, P. D., Choi, Y., and Littman, D. R. (2004). An essential function for the nuclear receptor RORgamma(t) in the generation of fetal lymphoid tissue inducer cells. Nat. Immunol. 5, 64-73.

Egawa, T., Eberl, G., Taniuchi, I., Benlagha, K., Geissmann, F., Hennighausen, L., et al. (2005). Genetic evidence supporting selection of the Valpha14i NKT cell lineage from double-positive thymocyte precursors. Immunity 22, 705-716.

Fathman, J. W., Bhattacharya, D., Inlay, M. A., Seita, J., Karsunky, H., and Weissman, I. L. (2011). Identification of the earliest natural killer cell-committed progenitor in murine bone marrow. Blood 118, 54395447.

Finke, D., Acha-Orbea, H., Mattis, A., Lipp, M., and Kraehenbuhl, J. (2002). CD4+CD3 - cells induce Peyer's patch development: role of alpha4betal integrin activation by CXCR5. Immunity 17, 363-373.

Gascoyne, D. M., Long, E., VeigaFernandes, H., de Boer, J., Williams, O., Seddon, B., et al. (2009). The basic leucine zipper transcription factor E4BP4 is essential for natural killer cell development. Nat. Immunol. 10, 1118-1124.

Gazit, R., Gruda, R., Elboim, M., Arnon, T. I., Katz, G., Achdout, H., et al. (2006). Lethal influenza infection in the absence of the natural killer cell receptor gene Ncr1. Nat. Immunol. 7 , 517-523.

Geremia, A., Arancibia-Carcamo, C. V., Fleming, M. P., Rust, N., Singh, B., Mortensen, N. J., et al. (2011). IL23-responsive innate lymphoid cells are increased in inflammatory bowel disease. J. Exp. Med. 208, 1127-1133.
Gordon, S. M., Chaix, J., Rupp, L. J., Wu, J., Madera, S., Sun, J. C., et al. (2012). The transcription factors T-bet and Eomes control key checkpoints of natural killer cell maturation. Immunity 36, 55-67.

Guo, Y., Maillard, I., Chakraborti, S., Rothenberg, E. V., and Speck, N. A. (2008). Core binding factors are necessary for natural killer cell development and cooperate with Notch signaling during T-cell specification. Blood 112, 480-492.

Gur, C., Porgador, A., Elboim, M., Gazit, R., Mizrahi, S., Stern-Ginossar, N. et al. (2010). The activating receptor NKp46 is essential for the development of type 1 diabetes. Nat. Immunol. 11, 121-128.

Hacker, C., Kirsch, R. D., Ju, X.S., Hieronymus, T, Gust, T. C. Kuhl, C., et al. (2003). Transcriptional profiling identifies Id 2 function in dendritic cell development. Nat. Immunol. 4, 380-386.

Halim, T. Y., Krauss, R. H., Sun, A. C., and Takei, F. (2012). Lung natural helper cells are a critical source of Th2 cell-type cytokines in protease allergen-induced airway inflammation. Immunity 36, 451-463.

Hamada, H., Hiroi, T., Nishiyama Y., Takahashi, H., Masunaga, Y., Hachimura, S., et al. (2002). Identification of multiple isolated lymphoid follicles on the antimesenteric wall of the mouse small intestine. $J$. Immunol. 168, 57-64.

Hamilton, B. A., Frankel, W. N., Kerrebrock, A. W., Hawkins, T. L., FitzHugh, W., Kusumi, K., et al. (1996). Disruption of the nuclear hormone receptor RORalpha in staggerer mice. Nature 379, 736-739.

Hayakawa, Y., Huntington, N. D., Nutt, S. L., and Smyth, M. J. (2006). Functional subsets of mouse natural killer cells. Immunol. Rev. 214, 47-55.

He, Y. W., Deftos, M. L., Ojala, E. W. and Bevan, M. J. (1998). RORgammat, a novel isoform of an orphan receptor, negatively regulates Fas ligand expression and IL-2 production in T cells. Immunity 9, 797-806.

Helbig, C., Gentek, R., Backer, R. A., de Souza, Y., Derks, I. A., Eldering, E., et al. (2012). Notch controls the magnitude of $\mathrm{T}$ helper cell responses by promoting cellular longevity. Proc Natl. Acad. Sci. U.S.A. 109, $9041-$ 9046.

Ho, I. C., Tai, T. S., and Pai, S. Y. (2009). GATA3 and the T-cell lineage: essential functions before and after T-helper-2-cell differentiation. Nat. Rev. Immunol. 9, 125-135.

Hosoya-Ohmura, S., Lin, Y. H., Herrmann, M., Kuroha, T., Rao, A.,
Moriguchi, T., et al. (2011). An NK and $\mathrm{T}$ cell enhancer lies 280 kilobase pairs $3^{\prime}$ to the gata3 structural gene. Mol. Cell. Biol. 31, 1894-1904.

Hoyler, T., Klose, C. S., Souabni, A., Turqueti-Neves, A., Pfeifer, D. Rawlins, E. L., et al. (2012). The transcription factor GATA-3 controls cell fate and maintenance of type 2 innate lymphoid cells. Immunity 37, 634-648.

Huber, S., Gagliani, N., Zenewicz, L. A., Huber, F. J., Bosurgi, L., Hu, B., et al. (2012). IL-22BP is regulated by the inflammasome and modulates tumorigenesis in the intestine. Nature 491, 259-263.

Huntington, N. D., Vosshenrich, C. A. J., and Di Santo, J. P. (2007). Developmental pathways that generate natural-killer-cell diversity in mice and humans. Nat. Rev. Immunol. 7, 703-714.

Iavarone, A., Garg, P., Lasorella, A., Hsu, J., and Israel, M. A. (1994). The helix-loop-helix protein Id-2 enhances cell proliferation and binds to the retinoblastoma protein. Genes Dev. 8, 1270-1284.

Ichikawa, M., Asai, T., Saito, T. Seo, S., Yamazaki, I., Yamagata, T., et al. (2004). AML-1 is required for megakaryocytic maturation and lymphocytic differentiation, but not for maintenance of hematopoietic stem cells in adult hematopoiesis. Nat. Med. 10, 299-304.

Ivanov, I. I., McKenzie, B. S., Zhou, L., Tadokoro, C. E., Lepelley, A., Lafaille, J. J., et al. (2006). The orphan nuclear receptor RORgammat directs the differentiation program of proinflammatory IL-17+ T helper cells. Cell 126, 1121-1133.

Jackson, J. T., Hu, Y., Liu, R., Masson, F., D’Amico, A., Carotta, S., et al. (2011). Id2 expression delineates differential checkpoints in the genetic program of CD8 $\alpha+$ and CD103+ dendritic cell lineages. EMBO J. 30, 2690-2704.

Jenne, C. N., Enders, A., Rivera, R., Watson, S. R., Bankovich, A. J., Pereira J. P., et al. (2009). T-bet-dependent S1P5 expression in NK cells promotes egress from lymph nodes and bone marrow. J. Exp. Med. 206, 2469-2481.

Kaech, S. M., and Cui, W. (2012). Transcriptional control of effector and memory CD8(+) $\mathrm{T}$ cell differentiation. Nat. Rev. Immunol. 12, 749-761. Kallies, A., Carotta, S., Huntington, N. D., Bernard, N. J., Tarlinton, D. M., Smyth, M. J., etal. (2011). A role for Blimpl in the transcriptional network controlling natural killer cell maturation. Blood 117, 1869-1879.

Kamizono, S., Duncan, G. S., Seidel, M. G., Morimoto, A., Hamada,
K., Grosveld, G., et al. (2009). Nfil3/E4bp4 is required for the development and maturation of NK cells in vivo. J. Exp. Med. 206, 29772986.

Kelly, K. A., and Scollay, R. (1992). Seeding of neonatal lymph nodes by $\mathrm{T}$ cells and identification of a novel population of CD3-CD4+ cells. Eur. J. Immunol. 22, 329-334.

Kennedy, M. K., Glaccum, M., Brown, S. N., Butz, E. A., Viney, J. L., Embers, M., et al. (2000). Reversible defects in natural killer and memory CD8 T cell lineages in interleukin 15-deficient mice. J. Exp. Med. 191, 771-780.

Kim, D., Mebius, R. E., MacMicking, J. D., Jung, S., Cupedo, T., Castellanos, Y., et al. (2000). Regulation of peripheral lymph node genesis by the tumor necrosis factor family member TRANCE. J. Exp. Med. 192, 1467-1478.

Kim, M. Y., Gaspal, F. M., Wiggett, H. E., McConnell, F. M., Gulbranson-Judge, A., Raykundalia, C., et al. (2003). CD4(+)CD3(-) accessory cells costimulate primed CD4 T cells through OX40 and CD30 at sites where T cells collaborate with B cells. Immunity 18 , 643-654.

Kim, M. Y., Rossi, S., Withers, D., McConnell, F., Toellner, K. M., Gaspal, F., et al. (2008). Heterogeneity of lymphoid tissue inducer cell populations present in embryonic and adult mouse lymphoid tissues. Immunology 124, 166-174.

Kim, S., Iizuka, K., H.-Kang, S. P., Dokun, A., French, A. R., Greco, S., et al. (2002). In vivo developmental stages in murine natural killer cell maturation. Nat. Immunol. 3, 523-528.

Kimura, A., Naka, T., Nohara, K., Fujii-Kuriyama, Y., and Kishimoto, T. (2008). Aryl hydrocarbon receptor regulates Stat 1 activation and participates in the development of Th17 cells. Proc. Natl. Acad. Sci. U.S.A. 105, 9721-9726.

Kiss, E. A., Vonarbourg, C., Kopfmann, S., Hobeika, E., Finke, D., Esser, C., et al. (2011). Natural aryl hydrocarbon receptor ligands control organogenesis of intestinal lymphoid follicles. Science 334, 15611565.

Kurebayashi, S., Ueda, E., Sakaue, M., Patel, D. D., Medvedev, A., Zhang, F., et al. (2000). Retinoid-related orphan receptor gamma (RORgamma) is essential for lymphoid organogenesis and controls apoptosis during thymopoiesis. Proc. Natl. Acad. Sci. U.S.A. 97, 10132-10137.

Lanier, L. L. (2005). NK cell recognition. Annu. Rev. Immunol. 23, 225-274. 
Lazarevic, V., and Glimcher, L. H. (2011). T-bet in disease. Nat. Immunol. 12, 597-606.

Lee, J. S., Cella, M., McDonald, K. G., Garlanda, C., Kennedy, G. D., Nukaya, M., et al. (2011). AHR drives the development of gut ILC22 cells and postnatal lymphoid tissues via pathways dependent on and independent of Notch. Nat. Immunol. 13, 144-151.

Liang, H. E., Reinhardt, R. L., Bando, J. K., Sullivan, B. M., Ho, I. C., and Locksley, R. M. (2012). Divergent expression patterns of IL-4 and IL13 define unique functions in allergic immunity. Nat. Immunol. 13, 58-66.

Liang, S. C., Tan, X. Y., Luxenberg, D. P., Karim, R., DunussiJoannopoulos, K., Collins, M., et al. (2006). Interleukin (IL)-22 and IL17 are coexpressed by Th17 cells and cooperatively enhance expression of antimicrobial peptides. J. Exp. Med. 203, 2271-2279.

Lorenz, R. G., Chaplin, D. D., McDonald, K. G., McDonough, J. S., and Newberry, R. D. (2003). Isolated lymphoid follicle formation is inducible and dependent upon lymphotoxinsufficient B lymphocytes, lymphotoxin beta receptor, and TNF receptor I function. J. Immunol. 170, 54755482.

Luci, C., Reynders, A., Ivanov, I. I., Cognet, C., Chiche, L., Chasson, L., et al. (2009). Influence of the transcription factor RORgammat on the development of NKp46+ cell populations in gut and skin. Nat. Immunol. $10,75-82$.

Mandelboim, O., Lieberman, N., Lev, M., Paul, L., Arnon, T. I., Bushkin, Y., et al. (2001). Recognition of haemagglutinins on virus-infected cells by NKp46 activates lysis by human NK cells. Nature 409, 1055-1060.

Mangelsdorf, D. J., Thummel, C., Beato, M., Herrlich, P., Schutz, G., Umesono, K., et al. (1995). The nuclear receptor superfamily: the second decade. Cell 83, 835-839.

Mebius, R. E. (2003). Organogenesis of lymphoid tissues. Nat. Rev. Immunol. 3, 292-303.

Mebius, R. E., Rennert, P., and Weissman, I. L. (1997). Developing lymph nodes collect CD4+CD3 - LTbeta+ cells that can differentiate to APC, NK cells, and follicular cells but not T or B cells. Immunity 7, 493-504.

Mebius, R. E., Streeter, P. R., Michie, S., Butcher, E. C., and Weissman, I. L. (1996). A developmental switch in lymphocyte homing receptor and endothelial vascular addressin expression regulates lymphocyte homing and permits CD4+
CD3 - cells to colonize lymph nodes. Proc. Natl. Acad. Sci. U.S.A. 93, 11019-11024.

Mezrich, J. D., Fechner, J. H., Zhang, X., Johnson, B. P., Burlingham, W. J., and Bradfield, C. A. (2010). An interaction between kynurenine and the aryl hydrocarbon receptor can generate regulatory T cells. J. Immunol. 185, 3190-3198.

Minter, L. M., Turley, D. M., Das, P., Shin, H. M., Joshi, I., Lawlor, R. G. et al. (2005). Inhibitors of gammasecretase block in vivo and in vitro $\mathrm{T}$ helper type 1 polarization by preventing Notch upregulation of Tbx 21 . Nat. Immunol. 6, 680-688.

Mjosberg, J., Bernink, J., Golebski, K., Karrich, J. J., Peters, C. P., Blom, B. et al. (2012). The transcription factor GATA3 is essential for the function of human type 2 innate lymphoid cells. Immunity 37, 649-659.

Mjosberg, J. M., Trifari, S., Crellin, N. K., Peters, C. P., van Drunen, C. M., Piet, B., etal. (2011). Human IL-25- and IL-33-responsive type 2 innate lymphoid cells are defined by expression of CRTH2 and CD161. Nat. Immunol. 12, 1055 1062.

Monticelli, L. A., Sonnenberg, G. F. Abt, M. C., Alenghat, T., Ziegler, C. G., Doering, T. A., et al. (2011). Innate lymphoid cells promote lungtissue homeostasis after infection with influenza virus. Nat. Immunol. 12, 1045-1054

Moro, K., Yamada, T., Tanabe, M. Takeuchi, T., Ikawa, T., Kawamoto, H., etal. (2010). Innate production of $\mathrm{T}(\mathrm{H}) 2$ cytokines by adipose tissueassociated c-Kit $(+) \mathrm{Sca}-1(+)$ lymphoid cells. Nature 463, 540-544.

Mrózek, E., Anderson, P., and Caligiuri, M. A. (1996). Role of interleukin15 in the development of human CD56+ natural killer cells from CD34+ hematopoietic progenitor cells. Blood 87, 2632-2640.

Murre, C., McCaw, P. S., and Baltimore, D. (1989a). A new DNA binding and dimerization motif in immunoglobulin enhancer binding, daughterless, MyoD, and myc proteins. Cell 56, 777-783.

Murre, C., McCaw, P. S., Vaessin, H., Caudy, M., Jan, L. Y., Jan, Y. N., et al. (1989b). Interactions between heterologous helix-loop-helix proteins generate complexes that bind specifically to a common DNA sequence. Cell 58, 537-544.

Narni-Mancinelli, E., Chaix, J., Fenis, A., Kerdiles, Y. M., Yessaad, N., Reynders, A., et al. (2011). Fate mapping analysis of lymphoid cells expressing the NKp46 cell surface receptor.
Proc. Natl. Acad. Sci. U.S.A. 108, 18324-18329.

Narni-Mancinelli, E., Jaeger, B. N., Bernat, C., Fenis, A., Kung, S., De Gassart, A., et al. (2012). Tuning of natural killer cell reactivity by NKp46 and Helios calibrates T cell responses. Science 335, 344-348.

Neill, D. R., and McKenzie, A. N J. (2011). Nuocytes and beyond: new insights into helminth expulsion. Trends Parasitol. 27, 214-221.

Neill, D. R., Wong, S. H., Bellosi, A., Flynn, R. J., Daly, M., Langford, T. K. A., et al. (2010). Nuocytes represent a new innate effector leukocyte that mediates type- 2 immunity. Nature 464, 1367-1370.

Nutt, S. L., Taubenheim, N., Hasbold, J., Corcoran, L. M., and Hodgkin, P. D. (2011). The genetic network controlling plasma cell differentiation. Semin. Immunol. 23, 341-349.

Ohno, S., Sato, T., Kohu, K., Takeda, K., Okumura, K., Satake, M., and Habu, S. (2008). Runx proteins are involved in regulation of CD122, Ly49 family and IFN-gamma expression during NK cell differentiation. Int. Immunol. 20, 71-79.

Okuda, T., van Deursen, J., Hiebert, S. W., Grosveld, G., and Downing, J. R. (1996). AML1, the target of multiple chromosomal translocations in human leukemia, is essential for normal fetal liver hematopoiesis. Cell 84, 321-330.

Orkin, S. H. (1992). GATA-binding transcription factors in hematopoietic cells. Blood 80, 575-581.

Ota, N., Wong, K., Valdez, P. A., Zheng, Y., Crellin, N. K., Diehl, L., et al. (2011). IL-22 bridges the lymphotoxin pathway with the maintenance of colonic lymphoid structures during infection with Citrobacter rodentium. Nat. Immunol. 12, 941-948.

Pabst, O., Herbrand, H., Friedrichsen, M., Velaga, S., Dorsch, M. Berhardt, G., et al. (2006). Adaptation of solitary intestinal lymphoid tissue in response to microbiota and chemokine receptor CCR7 signaling. J. Immunol. 177, 6824-6832.

Pickert, G., Neufert, C., Leppkes, M. Zheng, Y., Wittkopf, N., Warntjen, M., et al. (2009). STAT3 links IL-22 signaling in intestinal epithelial cells to mucosal wound healing. J. Exp. Med. 206, 1465-1472.

Possot, C., Schmutz, S., Chea, S., Boucontet, L., Louise, A., Cumano, A., and Golub, R. (2011). Notch signaling is necessary for adult, but not fetal, development of ROR $\gamma \mathrm{t}(+)$ innate lymphoid cells. Nat. Immunol. 12, 949-958.
Price, A. E., Liang, H.-E., Sullivan, B. M., Reinhardt, R. L., Eisley, C. J., Erle, D. J., et al. (2010). Systemically dispersed innate IL-13-expressing cells in type 2 immunity. Proc. Natl. Acad. Sci. U.S.A. 107, 11489-11494.

Qiu, J., Heller, J. J., Guo, X., Chen, Z. E., Fish, K., Fu, Y.-X., et al. (2012). The aryl hydrocarbon receptor regulates gut immunity through modulation of innate lymphoid cells. Immunity 36 , 92-104.

Quintana, F. J., Basso, A. S., Iglesias, A. H., Korn, T., Farez, M. F., Bettelli, E., et al. (2008). Control of T(reg) and $\mathrm{T}(\mathrm{H}) 17$ cell differentiation by the aryl hydrocarbon receptor. Nature 453, 65-71.

Ramirez, K., Chandler, K. J., Spaulding, C., Zandi, S., Sigvardsson, M., Graves, B. J., et al. (2012). Gene deregulation and chronic activation in natural killer cells deficient in the transcription factor ETS1. Immunity 36, 921-932.

Rankin, L., and Belz, G. T. (2011). Diverse roles of inhibitor of differentiation 2 in adaptive immunity. Clin. Dev. Immunol. 2011, 281569.

Rankin, L., Groom, J. R., Chopin, M., Herold, M. J., Walker, J. A., Mielke, L. A., et al. (2013). T-bet is essential for NKp46+ innate lymphocyte development through the Notch pathway. Nat. Immunol. (in press).

Ranson, T., Vosshenrich, C. A. J., Corcuff, E., Richard, O., Müller, W., and Di Santo, J. P. (2003). IL-15 is an essential mediator of peripheral NK-cell homeostasis. Blood 101, 4887-4893.

Raulet, D. H., Vance, R. E., and McMahon, C. W. (2001). Regulation of the natural killer cell receptor repertoire. Annu. Rev. Immunol. 19, 291-330.

Reynders, A., Yessaad, N., Vu Manh, T.-P., Dalod, M., Fenis, A., Aubry, C., et al. (2011). Identity, regulation and in vivo function of gut $\mathrm{NKp} 46(+) \mathrm{ROR} \gamma \mathrm{t}(+)$ and NKp46(+)ROR $\gamma \mathrm{t}(-)$ lymphoid cells. EMBO J. 30, 2934-2947.

Roberts, E. C., Deed, R. W., Inoue, T., Norton, J. D., and Sharrocks, A. D. (2001). Id helix-loop-helix proteins antagonize pax transcription factor activity by inhibiting DNA binding. Mol. Cell. Biol. 21, 524-533.

Rosmaraki, E. E., Douagi, I., Roth, C., Colucci, F., Cumano, A., and Di Santo, J. P. (2001). Identification of committed NK cell progenitors in adult murine bone marrow. Eur. J. Immunol. 31, 1900-1909.

Saenz, S. A., Siracusa, M. C., Perrigoue, J. G., Spencer, S. P., Urban, J. F., Tocker, J. E. Jr., et al. (2010). 
IL25 elicits a multipotent progenitor cell population that promotes $\mathrm{T}(\mathrm{H}) 2$ cytokine responses. Nature 464, 1362-1366.

Samson, S. I., Richard, O., Tavian, M., Ranson, T., Vosshenrich, C. A., Colucci, F., et al. (2003). GATA-3 promotes maturation, IFN-gamma production, and liver-specific homing of NK cells. Immunity 19, 701-711.

Sanos, S. L., Bui, V. L., Mortha, A., Oberle, K., Heners, C., Johner, C., et al. (2009). RORgammat and commensal microflora are required for the differentiation of mucosal interleukin 22-producing NKp46+ cells. Nat. Immunol. 10, 83-91.

Satoh-Takayama, N., Dumoutier, L., Lesjean-Pottier, S., Ribeiro, V. S. G., Mandelboim, O., Renauld, J.-C., et al. (2009). The natural cytotoxicity receptor NKp46 is dispensable for IL-22-mediated innate intestinal immune defense against Citrobacter rodentium. J. Immunol. 183, 6579 6587.

Satoh-Takayama, N., Lesjean-Pottier, S., Vieira, P., Sawa, S., Eberl, G., Vosshenrich, C. A. J., et al. (2010). IL-7 and IL-15 independently program the differentiation of intestinal CD3-NKp46+ cell subsets from Id2dependent precursors. J. Exp. Med. 207, 273-280.

Satoh-Takayama, N., Vosshenrich, C. A. J., Lesjean-Pottier, S., Sawa, S., Lochner, M., Rattis, F., et al. (2008). Microbial flora drives interleukin 22 production in intestinal NKp46+ cells that provide innate mucosal immune defense. Immunity 29, 958-970.

Sawa, S., Cherrier, M., Lochner, M., Satoh-Takayama, N., Fehling, H. J., Langa, F., et al. (2010). Lineage relationship analysis of RORgammat+ innate lymphoid cells. Science 330, 665-669.

Sawa, S., Lochner, M., Satoh-Takayama, N., Dulauroy, S., Bérard, M., Kleinschek, M., et al. (2011). ROR $\gamma \mathrm{t}+$ innate lymphoid cells regulate intestinal homeostasis by integrating negative signals from the symbiotic microbiota. Nat. Immunol. 12, 320-326.

Scanlon, S. T., and McKenzie, A. N. (2012). Type 2 innate lymphoid cells: new players in asthma and allergy. Curr. Opin. Immunol. 24, 707-712.

Setoguchi, R., Tachibana, M., Naoe, Y., Muroi, S., Akiyama, K., Tezuka, C., et al. (2008). Repression of the transcription factor Th-POK by Runx complexes in cytotoxic T cell development. Science 319, 822-825.

Sonnenberg, G. F., Monticelli, L. A., Alenghat, T., Fung, T. C., Hutnick,
N. A., Kunisawa, J., et al. (2012). Innate lymphoid cells promote anatomical containment of lymphoid-resident commensal bacteria. Science 336, 1321-1325.

Sonnenberg, G. F., Monticelli, L. A. Elloso, M. M., Fouser, L. A., and Artis, D. (2011). CD4(+) lymphoid tissue-inducer cells promote innate immunity in the gut. Immunity 34, 122-134.

Spits, H., and Cupedo, T. (2012). Innate lymphoid cells: emerging insights in development, lineage relationships, and function. Annu. Rev. Immunol. 30, 647-675.

Spits, H., and Di Santo, J. P. (2011). The expanding family of innate lymphoid cells: regulators and effectors of immunity and tissue remodeling. Nat. Immunol. 12, 21-27.

Spits, H., Artis, D., Colonna, M. Diefenbach, A., Di Santo, J. P., Eberl, G., et al. (2013). Innate lymphoid cells - a proposal for a uniform nomenclature. Nat. Rev. Immunol. 13, 145-149.

Sugimoto, K. (2008). Role of STAT3 in inflammatory bowel disease. World J. Gastroenterol. 14, 5110-5114.

Sun, J. C., and Lanier, L. L. (2011). NK cell development, homeostasis and function: parallels with CD8(+) $\mathrm{T}$ cells. Nat. Rev. Immunol. 11, 645-657.

Sun, X. H., Copeland, N. G., Jenkins, N. A., and Baltimore, D. (1991). Id proteins Id1 and Id2 selectively inhibit DNA binding by one class of helixloop-helix proteins. Mol. Cell. Biol. 11, 5603-5611.

Sun, Z., Unutmaz, D., Zou, Y. R., Sunshine, M. J., Pierani, A., BrennerMorton, S., et al. (2000). Requirement for RORgamma in thymocyte survival and lymphoid organ development. Science 288, 23692373.

Tachibana, M., Tenno, M., Tezuka, C., Sugiyama, M., Yoshida, H., and Taniuchi, I. (2011). Runx1/Cbf $\beta 2$ complexes are required for lymphoid tissue inducer cell differentiation at two developmental stages. J. Immunol. 186, 1450-1457.

Tait Wojno, E. D., and Artis, D. (2012). Innate lymphoid cells: balancing immunity, inflammation, and tissue repair in the intestine. Cell Host Microbe 12, 445-457.

Takatori, H., Kanno, Y., Watford, W T., Tato, C. M., Weiss, G., Ivanov, I. I., et al. (2009). Lymphoid tissue inducer-like cells are an innate source of IL-17 and IL-22. J. Exp. Med. 206, 35-41.

Takeda, K., Cretney, E., Hayakawa, Y., Ota, T., Akiba, H., Ogasawara, K., et al. (2005). TRAIL identifies immature natural killer cells in newborn mice and adult mouse liver. Blood 105, 2082-2089.

Townsend, M. J., Weinmann, A. S., Matsuda, J. L., Salomon, R., Farnham, P. J., Biron, C. A., et al. (2004). T-bet regulates the terminal maturation and homeostasis of $\mathrm{NK}$ and Valpha14i NKT cells. Immunity 20, 477-494.

Trinchieri, G. (1989). Biology of natural killer cells. Adv. Immunol. 47, 187-376.

Tsuji, M., Suzuki, K,. Kitamura, H., Maruya, M., Kinoshita, K., Ivanov, K. II, et al. (2008). Requirement for lymphoid tissue-inducer cells in isolated follicle formation and $\mathrm{T}$ cellindependent immunoglobulin A generation in the gut. Immunity 29 , 261-271.

Veldhoen, M., Hirota, K., Christensen, J., O'Garra, A., and Stockinger, B. (2009). Natural agonists for aryl hydrocarbon receptor in culture medium are essential for optimal differentiation of Th17 T cells. J. Exp. Med. 206, 43-49.

Villey, I., de Chasseval, R., and de Villartay, J. P. (1999). RORgammaT, a thymus-specific isoform of the orphan nuclear receptor RORgamma/TOR, is up-regulated by signaling through the pre-T cell receptor and binds to the TEA promoter. Eur. J. Immunol. 29, 40724080.

Vivier, E., Raulet, D. H., Moretta, A., Caligiuri, M. A., Zitvogel, L., Lanier, L. L., et al. (2011). Innate or adaptive immunity? The example of natural killer cells. Science 331, 44-49.

Vivier, E., Spits, H., and Cupedo, T. (2009). Interleukin-22-producing innate immune cells: new players in mucosal immunity and tissue repair? Nat. Rev. Immunol. 9, 229-234.

Vonarbourg, C., Mortha, A., Bui, V. L., Hernandez, P. P., Kiss, E. A., Hoyler, M., et al. (2010). Regulated expression of nuclear receptor ROR $\gamma \mathrm{t}$ confers distinct functional fates to NK cell receptor-expressing $\mathrm{ROR} \gamma \mathrm{t}(+)$ innate lymphocytes. Immunity 33 , 736-751.

Voronova, A. F., and Lee, F. (1994) The E2A and tal-1 helix-loop-helix proteins associate in vivo and are modulated by Id proteins during interleukin 6-induced myeloid differentiation. Proc. Natl. Acad. Sci. U.S.A 91, 5952-5956.

Vosshenrich, C. A. J., García-Ojeda, M. E., Samson-Villéger, S. I., Pasqualetto, V., Enault, L., Richard-Le, O., et al. (2006). A thymic pathway of mouse natural killer cell development characterized by expression of GATA-3 and CD127. Nat. Immunol. 7, 12171224.

Wilhelm, C., Hirota, K., Stieglitz, B., Van Snick, J., Tolaini, M., Lahl, K., et al. (2011). An IL-9 fate reporter demonstrates the induction of an innate IL-9 response in lung inflammation. Nat. Immunol. 12, 10711077.

Wilkinson, B., Chen, J. Y.-F., Han, P., Rufner, K. M., Goularte, O. D., and Kaye, J. (2002). TOX: an HMG box protein implicated in the regulation of thymocyte selection. Nat. Immunol. 3, 272-280.

Wolk, K., Kunz, S., Witte, E., Friedrich, M., Asadullah, K., and Sabat, R. (2004). IL-22 increases the innate immunity of tissues. Immunity 21 , 241-254.

Wong, S. H., Walker, J. A., Jolin, H. E., Drynan, L. F., Hams, E., Camelo, A., et al. (2012). Transcription factor ROR $\alpha$ is critical for nuocyte development. Nat. Immunol. 13, 229-236.

Yates, P. R., Atherton, G. T., Deed, R. W., Norton, J. D., and Sharrocks, A. D. (1999). Id helix-loop-helix proteins inhibit nucleoprotein complex formation by the TCF ETS-domain transcription factors. EMBO J. 18, 968-976.

Yokota, Y., Mansouri, A., Mori, S., Sugawara, S., Adachi, S., Nishikawa, S., et al. (1999). Development of peripheral lymphoid organs and natural killer cells depends on the helixloop-helix inhibitor Id2. Nature 397, 702-706.

Yoshida, H., Honda, K., Shinkura, R., Adachi, S., Nishikawa, S., Maki, K., et al. (1999). IL-7 receptor alpha+ CD3(-) cells in the embryonic intestine induces the organizing center of Peyer's patches. Int. Immunol. 11, 643-655.

Yoshida, H., Naito, A., Inoue, J.I., Satoh, M., Santee-Cooper, S. M., Ware, C. F., et al. (2002). Different cytokines induce surface lymphotoxin-alphabeta on IL-7 receptor-alpha cells that differentially engender lymph nodes and Peyer's patches. Immunity 17, 823-833.

Yun, S., Lee, S. H., Yoon, S. R., Kim, M. S., Piao, Z. H., Myung, P. K., et al. (2011). TOX regulates the differentiation of human natural killer cells from hematopoietic stem cells in vitro. Immunol. Lett. 136, 29-36.

Zheng, Y., Danilenko, D. M., Valdez, P., Kasman, I., Eastham-Anderson, J., $\mathrm{Wu}$, J., et al. (2007). Interleukin-22, 
a $\mathrm{T}(\mathrm{H}) 17$ cytokine, mediates IL-23-induced dermal inflammation and acanthosis. Nature 445, 648-651.

Zheng, Y., Valdez, P. A., Danilenko, D. M., Hu, Y., Sa, S. M., Gong, Q., et al. (2008). Interleukin-22 mediates early host defense against attaching and effacing bacterial pathogens. Nat. Med. 14, 282-289.
Conflict of Interest Statement: The authors declare that the research was conducted in the absence of any commercial or financial relationships that could be construed as a potential conflict of interest.

Received: 04 November 2012; accepted: 16 January 2013; published online: 04 March 2013.
Citation: Rankin L, Groom J, Mielke LA, Seillet $C$ and Belz GT (2013) Diversity, function, and transcriptional regulation of gut innate lymphocytes. Front. Immunol. 4:22. doi: 10.3389/fimmu. 2013.00022

This article was submitted to Frontiers in NK Cell Biology, a specialty of Frontiers in Immunology.
Copyright (C) 2013 Rankin, Groom, Mielke, Seillet and Belz. This is an open-access article distributed under the terms of the Creative Commons Attribution License, which permits use, distribution and reproduction in other forums, provided the original authors and source are credited and subject to any copyright notices concerning any thirdparty graphics etc. 